\title{
CNX-013-B2, a unique pan tissue acting rexinoid, modulates several nuclear receptors and controls multiple risk factors of the metabolic syndrome without risk of hypertriglyceridemia, hepatomegaly and body weight gain in animal models
}

Manoj Kumar Sadasivuni ${ }^{\dagger}$, Bobbili Madhusudhan Reddy ${ }^{\dagger}$, Jaideep Singh $^{\dagger}$, Mammen O Anup, Venkategowda Sunil, Mudigere N Lakshmi, Sivakumaran Yogeshwari, Suni K Chacko, Talanki Lokesh Pooja, Anilkumar Dandu, Chandrashekaran Harish, Aralakuppe S Gopala, Shivakumar Pratibha, Baisani S Naveenkumar, Puttrevana M Pallavi, Mahesh Kumar Verma, Yoganand Moolemath, Baggavalli P Somesh, Marikunte V Venkataranganna and Madanahalli R Jagannath*

\begin{abstract}
Background: In addition to their role in growth, cellular differentiation and homeostasis Retinoid X Receptors (RXR) regulate multiple physiological and metabolic pathways in various organs that have beneficial glucose and lipid (cholesterol) lowering, insulin sensitizing and anti-obesity effects. Rexinoids, compounds that specifically binds and activate RXR, are therefore considered as potential therapeutics for treating metabolic syndrome. Apparently many of the rexinoids developed in the past increased triglycerides, caused hepatomegaly and also suppressed the thyroid hormone axis. The aim of this study is to evaluate CNX-013-B2, a potent and highly selective rexinoid, for its potential to treat multiple risk factors of the metabolic syndrome.

Methods: CNX-013-B2 was selected in a screening system designed to identify compounds that selectively activated only a chosen sub-set of heterodimer partners of RXR of importance to treat insulin resistance. Male C57BL/6j mice $(n=10)$ on high fat diet (HFD) and 16 week old ob/ob mice $(n=8)$ were treated orally with CNX-013-B2 (10 mg/kg twice daily) or vehicle for 10 weeks and 4 weeks respectively. Measurement of plasma glucose, triglyceride, cholesterol including LDL-C, glycerol, free fatty acids, feed intake, body weight, oral glucose tolerance and non-shivering thermogenesis were performed at selected time points. After study termination such measurements as organ weight, triglyceride content, mRNA levels, protein phosphorylation along with histological analysis were performed.
\end{abstract}

Results: CNX-013-B2 selectively activates PPARs- $a, \beta / \delta$ and $\gamma$ and modulates activity of LXR, THR and FXR. In ob/ob mice a significant reduction of $25 \%$ in fed glucose $(p<0.001)$, a 14\% $(p<0.05)$ reduction in serum total cholesterol and $18 \%$ decrease $(p<0.01)$ in LDL-C and in DIO mice a reduction of 12\% $(p<0.01)$ in fasting glucose, 20\% in fed triglyceride $(p<0.01)$ and total cholesterol $(p<0.001)$ levels, coupled with enhanced insulin sensitivity, cold induced thermogenesis and $7 \%$ reduction in body weight were observed.

(Continued on next page)

\footnotetext{
* Correspondence: m.r.jagannath@connexios.com

${ }^{\dagger}$ Equal contributors

Connexios Life Sciences Pvt Ltd, Bangalore, India
} 
(Continued from previous page)

Conclusion: CNX-013-B2 is an orally bio available selective rexinoid that can be used as a novel therapeutic agent for management of multiple risk factors of the metabolic syndrome without the risk of side effects reported to be associated with rexinoids.

Keywords: Diabetes, Dyslipidemia, PPAR pan-activator, Insulin sensitizer, Exercise mimetic, CHF, Steatosis

\section{Introduction}

Metabolic syndrome is a cluster of risk factors comprising raised plasma glucose, abdominal obesity and high blood pressure all of which increase mortality due to cardiovascular disease. Management of metabolic syndrome includes behavioural changes aimed at promoting weight loss through dietary modifications and exercise and a combination of therapies directed to reduce specific metabolic risk factors [1]. In addition to diabetic dyslipidemia and insulin resistance such others factors as inflammation, oxidative stress, enhanced matrix metalloproteinase activity, activation of local renin angiotensin system and the accumulation of advanced glycation end-products contribute to the development and progression of macrovascular disease in diabetes.

Peroxisome Proliferator-Activated Receptors (PPAR), members of the nuclear receptor family of transcription factors, participates in molecular pathways that can modify a host of aforesaid biochemical pathways [2-6]. PPARy agonists, rosiglitazone and pioglitazone enhance insulin sensitivity, lower hyperglycemia and free fatty acid concentrations by improving glucose and lipid metabolism, improves adipokine profile and reduce adipose tissue inflammation [7-9]. PPAR $\alpha$ agonists, Fibrates, lower triglycerides, increase HDL-cholesterol, normalise low density lipoprotein size distribution and also display anti-inflammatory and antiatherosclerotic effects [9-12]. Activation of PPAR $\delta$ in preclinical studies has displayed potential to control weight gain, enhance physical endurance, improve insulin sensitivity and ameliorate atherosclerosis [13]. The adverse side effects of rosiglitazone include weight gain, bone fractures, fluid retention, edema congestive heart failure all leading to myocardial infarction and ischemic cardiovascular events. On the other hand pioglitazone induces weight gain, increases fluid retention and possibly increased fractures and bladder cancer. The adverse side effects associated with fibrates include elevated serum creatinine, myopathy and rhabdomyolysis [9].

Attempts to improve safety profile of PPAR agonists have looked at balancing the relative potency and/or activity towards PPAR $\alpha$ or PPAR $\gamma$ and also the selectivity/ potency of cofactor recruitment as both these traits would likely demonstrate high levels of efficacy but with improved safety profile. Dual PPAR agonists were developed to combine the beneficial effects of PPAR $\alpha$ and PPAR $\gamma$ for addressing $\mathrm{CV}$ risk in patients with T2DM. Muraglitazar, a dual PPAR $\alpha / \gamma$ agonist with greater potency towards PPAR $\gamma$, improved HbA1c and lipid profile but caused higher edema, CHF and $\mathrm{CV}$ deaths and development was subsequently stopped. Tesaglitazar, a dual PPAR $\alpha / \gamma$ agonist with greated potency towards PPAR $\alpha$ as against PPAR $\gamma$ was discontinued due to increase in body weight, edema and serum creatinine levels [9]. Recently development of Aleglitazar, a balanced activator of PPAR $\alpha$ and PPAR $\gamma$ was discontinued in phase III due to safety signal and lack of efficacy.

It became clear that in the activation of PPARy by a full agonist the dose response curve relation for multiple activities appeared to be linked while in case of a selective modulator the dose response relations between different activities were completely uncoupled. Selective peroxisome proliferator-activated receptor $\gamma$ modulators (SPPARM) that display potent and highly efficacious insulin sensitization but low potency for side effects are being developed [14]. While many SPPSRMs are in preclinical development INT131 has displayed lowering of plasma glucose without typical thioazolidindione side effects in patients with T2DM [15].

Simultaneous activation of PPAR $\alpha$ PPAR $\delta$ and PPAR $\gamma$ by a single compound is being pursued to treat the multiple defects associated with insulin resistance, type 2 diabetes and the metabolic syndrome [16]. Currently bezafibrate is reported to operate as a pan-agonist of all the three PPAR isoforms and has been effective in reducing insulin resistance, glucose, HbA1c, small dense LDL particles, atherosclerotic plaque regression and improves endothelial function [17].

LXR agonists display significant anti-diabetic activities in diabetic rodent models but are associated with the risk of hypertriglyceridemia and liver steatosis [18] while synthetic selective thyroid hormone (TH) receptor (TR) modulators (STRM) reduce dyslipidemia, obesity, fatty liver, and insulin resistance in preclinical animal models [19].

Retinoid X Receptors (RXR) are members of the nuclear receptor family of transcription factors that function as a 'sensor' receptor by binding specific liphophilic ligand and modulating gene expression. RXRs are considered 'promiscuous' as they form heterodimers with several other nuclear receptor family members. In addition RXRs are also known to exist as homodimers and homotetramers which can control their own signaling pathways. Binding of RXR ligands to heterodimers are reported to enhance 
transcriptional activation by RXR partner receptors. Three genes encode the Retinoid X Receptors - RXR $\alpha, \operatorname{RXR} \beta$ and $R X R \gamma$. Expression of RXR $\alpha$ is predominant in liver, RXR $\beta$ in CNS and RXRY in skeletal muscle and some regions of CNS [20].

RXR $\alpha$ appears to have an important role in development as germline mutations are in utero lethal while mice expressing single RXR allele $\left(\mathrm{RXR}^{-/-}\right.$or $\mathrm{RXR} \gamma^{-/-}$) are completely viable indicating functional redundancy [21]. Similarly hepatocytes specific inactivation $\operatorname{RXR} \alpha$ produces strong phenotype indicating a major role for $\operatorname{RXR} \alpha$ [22]. It is apparent that retinoic acid receptors display distinct functions inspite of common heterodimerization partners [20]. RXR $\alpha$ plays an important role in pathways modulating cholesterol, fatty acid, bile acid, steroid and xenobiotic metabolism and homeostasis [23] in liver and modulates adipogenesis and lipolysis [24] in adipocytes. RXRY has been demonstrated to control gene expression to enhance insulin sensitization and glucose disposal, increase uptake and oxidation of saturated fatty acids, increase desaturation of fatty acids and regulate oxidative slow-twitch phenotype [25]. RXR agonists have also been shown to activate PPAR $\alpha$-inducible genes and lower triglycerides and raise HDL levels in vivo [26], reduce atherosclerosis in apoE knockout mice [27] and activate RXR:PPAR $\gamma$ heterodimer to reduce hyperglycemia, hypertriglyceridemia and hyperinsulinemia [28].

While rexinoids have demonstrated insulin sensitizing, glucose lowering and anti-obesity effects in animal models of disease they have been associated with undesirable effects as hypertriglyceridemia and suppression of the thyroid hormone axis both in animals and in humans [29]. It is the considered opinion of several investigators that a rexinoid that is selective and activates receptor complexes of benefit to insulin resistance could be of major therapeutic significance.

In this study we report the development of a heterodimer selective rexinoid, CNX-013-B2, that provides significant control of insulin resistance, hyperinsulinemia, glucose, lipid and body weight in mice models of disease. Specifically pharmacological effect of CNX-013-B2 is devoid of the commonly observed side effects associated with many PPARY and RXR agonists. CNX-013-B2 is a safe and efficacious therapeutic with potential to compliment the current standard of care to provide robust and long term control of the various risk factors associated with the metabolic syndrome.

\section{Material and methods Reagents and kits}

Includes Accu-check glucometer (Roche Diagnostics, Germany), Ultra-sensitive insulin ELISA kit (Crystal Chem Inc, USA), TAG estimation kit (Diasys Diagnostics system,
Germany), FFA estimation kit (Randox Laboratories, UK), Cholesterol estimation kit (Diasys Diagnostics system, Germany, cat\# 113009910704), Glycerol estimation kits (Sigma, cat\#F6428). Triton-X and Fluromount were procured from Sigma-Aldrich. Bexarotene (Sigma).

\section{Transactivation assay}

HEK-293 cells (ATCC) were seeded one day prior to transfection. For assessing EC50 of activation of RXR isoforms $2 \mu \mathrm{g}$ of hRXR $\alpha, \beta$, or $\gamma$ (OriGENE, USA) over-expressing vector, $1 \mu \mathrm{g}$ of plasmid expressing firefly luciferase under RARE element (RARE-Luc) and $25 \mathrm{ng}$ of renilla luciferase vector (QIAGEN, USA) were co-transfected using lipofectamine reagent. For assessing transactivation of heterodimer partners $2 \mu \mathrm{g}$ each of $\mathrm{hRXR} \alpha / \mathrm{hLXR} \alpha, \mathrm{hRXR} \alpha /$ RAR $\alpha, h R X R \alpha / P P A R \alpha, h R X R \alpha / P P A R ~ \gamma$ and hRXR $\gamma /$ PPAR $\delta$ (OriGENE, USA) were co-transfected alongwith $1 \mu \mathrm{g}$ of plasmid expressing firefly luciferase under respective LXRE, XRE or PPRE element and 25 ng of renilla luciferase vector. After $24 \mathrm{~h}$ of transfection, cells were treated with different concentrations of CNX-013-B2 for $24 \mathrm{~h}$ followed by estimation of luciferase activity using Dual Luciferase Reporter Assay System (Promega). Luciferase activity was normalized to that of renilla luciferase. For EC50 determination, activation was measured at different concentration of CNX-013-B2 (1, 5, 10, 50, 100, 500, 1000 and $5000 \mathrm{nM})$. EC50 was calculated using Graphpad prism software.

\section{Study in C57BL/6j mice on high fat diet}

Six week old male C57BL/6 J mice were housed 2 per polypropylene cage, maintained at $23 \pm 1^{\circ} \mathrm{C}, 60 \pm 10 \%$ humidity, exposed to 12 hour cycles of light and dark and provided ad libitum access to either chow, $10 \% \mathrm{kcal}$ from fat or high fat diet, HFD D12492, 60\% kcal from fat (both from Research Diets, USA) and water. All the study protocols, animal maintenance and experimental procedures were approved by the Institutional Animal Ethics Committee (IAEC) of Connexios Life Sciences, which is according to the CPCSEA (Committee for the Purpose of Control and Supervision of Experiments on Animals) guidelines, Govt. of India. Post high fat feeding for 11 weeks animals were randomized to specific treatment groups based on body weight, glucose AUC during OGTT, fasting and fed blood glucose and fasting TG levels.

Animals $(n=10)$ in the lean control group were fed normal chow diet while animals in the treatment group $(\mathrm{n}=10)$ and DIO control group $(\mathrm{n}=10)$ were fed high fat diet throughout the experimental period. Animals in the treatment group received $10 \mathrm{mg} / \mathrm{kg} \mathrm{CNX}-013-\mathrm{B} 2$, twice daily, po as suspension in $1 \% \mathrm{MC}$ (methyl cellulose) as vehicle. Lean control and DIO controls animals were administered only vehicle. Body weight (weekly) and feed 
consumption, as average for 2 animals (daily), were recorded. Blood collected from tail vein after $24 \mathrm{~h}$ of the previous dose was subjected to glucose and triglyceride estimation. oGTT was performed in $6 \mathrm{~h}$ fasted mice with $2 \mathrm{~g} / \mathrm{kg}$, of oral glucose challenge. After 10 weeks of treatment blood collected from retro-orbital bleeding was used for estimation of glycerol, free fatty acid, total cholesterol and LDL-C. Blood was collected in the fed state for cholesterol estimation and for estimation of all other parameters blood was collected in the fasting state. Animals were euthanized post $6 \mathrm{~h}$ fasting under isoflurane anaesthesia, necropsied and liver excised immediately, weighed and taken for estimation of triglyceride. Different adipose depots were separated and weighed.

\section{Study in ob/ob mice}

Male ob/ob and lean C57BL/6 J mice were procured from Harlan laboratories, acclimatized and fed a standard laboratory diet. The lean control and the ob/ob mice were 16 weeks old at the start of the study and were randomized to either vehicle or drug (CNX-013-B2- $10 \mathrm{mg} / \mathrm{kg}$, BID, po) treatment groups based on body weight, fed glucose and glucose AUC determined in an oral glucose tolerance test (oGTT).

The animals were treated for 4 weeks and during the study body weight, food intake, fed glucose and fasting triglycerides were monitored at regular intervals. In an oGTT performed at end of the study glucose levels were determined at different time intervals post glucose load. Serum collected, before animals were euthanized under isoflurane anaesthesia, was used for estimation of glycerol, free fatty acid, cholesterol and LDL-C.

\section{Oral glucose tolerance test (oGTT)}

CNX-013-B2 or vehicle was administered to $6 \mathrm{~h}$ fasted animals $30 \mathrm{~min}$ prior to administration of glucose $(2 \mathrm{~g} / \mathrm{kg}$ b. wt) by oral gavage. Blood samples collected from the tail vein 30 min before treatment and at 0, 15, 30, 60, 90, 120 and $180 \mathrm{~min}$ after glucose load was used for estimating plasma glucose and insulin.

\section{Measurement of thermogenesis}

For assessing cold induced thermogenesis in DIO mice, animals were housed in a cold environment with an ambient temperature of $4^{\circ} \mathrm{C}$ and body temperature was determined every $15 \mathrm{~min}$ for a total of $75 \mathrm{~min}$ using a rectal probe. The animals were then shifted to room temperature and rectal temperature was measured at 10 minutes interval for a further 20 min period.

\section{Estimation of total cholesterol, LDL-C, glycerol and FFA}

Blood collected by retro orbital route under Isoflurane anesthesia was allowed to clot for $30 \mathrm{~min}$ at room temperature, centrifuged at $10000 \mathrm{rpm}$ for 10 minutes at $4^{\circ} \mathrm{C}$ and the serum was collected for further analysis. Serum total Cholesterol was measured using fully automated clinical chemistry analyzer EM360, (Transasia Bio-medicals Ltd) with ERBA Kits. LDLc was estimated by colorimetry using Diasys kit as per the manufacturer's protocol. Glycerol was estimated by Colorimetric method using Sigma Kit and FFA by Randox kit.

\section{Estimation of tissue TG and cholesterol}

Tissue TG and Cholesterol were extracted according to Folch's method. Briefly, $1 \mathrm{ml}$ of $10 \%$ tissue homogenate was extracted with $5 \mathrm{ml}$ of chloroform: methanol (2:1) mixture, the organic layer was separated and dried in a speed vac. The residue was re-suspended in isopropyl alcohol and TG and cholesterol levels were estimated by using TAG kit and cholesterol kit respectively from Diasys (Diasys Diagnostics system, Germany).

\section{Histochemical and histological analysis of liver}

To examine morphology formalin-fixed liver samples were paraffin-embedded, sectioned at $5 \mu \mathrm{m}$ and stained with hematoxylin and eosin $(\mathrm{H} \& \mathrm{E})$. All slides were examined under light microscopy at low (10X), (40X) and high (100X) magnification. For glycogen staining, sections were deparaffinized, hydrated and immersed in periodic acid solution for 5 minutes at room temperature. After rinsing in distilled water, the sections were covered with Schiff's reagent for 15 minutes at room temperature and washed in running tap water for 5 minutes. The sections were counterstained with Mayer's hematoxylin for 90 seconds, rinsed in running tap water, dehydrated, cleared and mounted under DPX mountant.

Adipocyte size measurement Formalin-fixed adipose tissue from various depots was paraffin-embedded, sectioned at $5 \mu \mathrm{m}$ and stained with hematoxylin and eosin (H\&E) and 10 different microscopic fields photographed at $400 \times$ magnification. Morphometry of the captured images was performed using ProgRes Pro, v.2.8.8 image analysis suite. The adipocytes were traced along their perimeter and area was calculated. The mean area of adipocytes from all the groups were statistically analysed using Graphpad Prism, v.5.0.

UCP1 expression in adipocytes Formalin fixed paraffin embedded adipose tissue sections, from both inguinal and intra scapular brown adipose depots, were deparffinized in xylene and subjected to antigen retrieval in citrate buffer, followed by washing in buffer Triton X-Phosphate Buffered Saline (PBS) and blocked using $1 \%$ bovine serum albumin in PBS. The blocked tissue sections were incubated with anti-UCP1 primary antibody (1:50) for 1 hour. Alexa-Fluor 555 tagged secondary antibody (goat-anti-rat IgG, 1:100) was used for 
detection. After 45 minutes of incubation with secondary antibody, the sections were washed and wet mounted for examination under fluorescence microscope (Zeiss AX100). From immunofluorescence stained sections 30 different microscopic fields per sections were randomly selected. The images of each microscopic field were captured using ProgRes Pro, v.2.8.8 image analysis suite at a magnification 400X. The adipocytes positive for UCP1 expression were manually counted in all 30 microscopic fields and expressed as mean \pm SEM.

\section{Measurement of succinate dehydrogenase activity}

Gastrocnemius muscle pieces (10-12 mg/animal) were obtained from the animals and washed with KRBH media and incubated in $100 \mathrm{mM}$ potassium phosphate buffer containing $50 \mathrm{mM}$ sucrose, $10 \mathrm{mM}$ sodium azide, 500 $\mathrm{mM}$ sodium succinate and $8 \mathrm{mM}$ INT (Iodonitrotetrazolium chloride; Sigma) for $2 \mathrm{~h}$. Muscle tissue samples without sodium succinate were used as negative control. After $2 \mathrm{~h}$ at $37^{\circ} \mathrm{C}$, INT was dissolved in DMSO by vertexing and estimated at $644 \mathrm{~nm}$. The difference in absorbance with/ without succinate was calculated, normalized to total weight of muscle and represented as \% control SDH activity.

RNA isolation, reverse transcription and quantitative real time polymerase chain reaction (qPCR)

Total RNA was isolated from $100 \mathrm{mg}$ of different tissues using Tri-reagent (Sigma, USA) as per manufacturer's instructions and 2 ug of RNA was converted into cDNA by reverse transcription (ABI, USA) using the standard PCR method. Gene expression was measured using SYBR Green PCR Master Mix (Eurogenetic, Belgium) and relative levels of expression were quantified using $18 \mathrm{~S}$ rRNA/ Beta actin/RPL13 as control housekeeping gene. The primer sequences for the genes analyzed are given in the supplementary table.

\section{Western blot}

After 10 weeks of treatment of DIO mice on HFD and 4 weeks of treatment of ob/ob mice, animals in all experimental groups were sacrificed and $10 \mathrm{mg}$ each of tissue samples was collected from muscle (gastrocnemius), adipose (mesenteric and inguinal) and liver from each animal. Lysates $(50 \mu \mathrm{g}$ each from liver, muscle and adipose) were prepared by homogenization and subjected to SDS-PAGE, transferred onto nitrocellulose membranes, probed with primary antibody against pPPAR- $\gamma$ (Ser 273, Cell Signaling), $\beta$-actin, p-AKT, p-JNK, total JNK, IKK- $\beta$ and total AKT (Cell signaling, USA) and developed by enhanced chemiluminescence (West Pico, Thermo Scientific, USA). The relative levels of $\mathrm{p}$-AKT compared to Total AKT were quantified using Image J Ver. 4.2, NIH, Bethesda. For p-AKT measurement in mesenteric adipose tissue of DIO mice study, adipose tissues were incubated with or without 30nM insulin for $10 \mathrm{~min}$. After the incubation period, tissues were processed for $\mathrm{p}$-AKT measurement as mentioned above.

\section{Statistical analysis}

All the values are expressed as Mean \pm SEM; one way analysis of variance was performed followed by Dunnets, test for establishing the significance value of the treatment groups when compared with DIO control or ob/ob control. $\mathrm{p}<0.05$ was considered as statistically significant.

\section{Results}

\section{CNX-013-B2 is a potent and selective rexinoid}

HEK293 cells (Human embryonic Kidney cells) were used as model system to measure the transcriptional activation of transiently overexpressing RXR isoforms alone or RXR isoform co-transfected with LXR $\alpha$ or RAR $\alpha$ or PPAR $\alpha$ or PPAR $\delta$ or PPAR $\gamma$ overexpressing vectors by CNX-013-B2. Reporter assay indicated that treatment with CNX-013-B2 almost uniformly activated all three RXR isoforms in a dose dependent manner and the calculated EC50 determined was $48 \mathrm{nM}, 66 \mathrm{nM}$ and $68 \mathrm{nM}$ towards RXR $\alpha$, RXR $\delta$ and $\mathrm{RXR} \gamma$ respectively. Treatment with CNX-013-B2 enhanced transcriptional activity of RXR/PPAR isoforms and the EC50 for activation of RXR/PPAR $\alpha$, RXR/PPAR $\delta$ and RXR/PPAR $\gamma$ was determined as $159 \mathrm{nM}, 178 \mathrm{nM}$ and $196 \mathrm{nM}$ respectively (Table 1 ). It is important to note that CNX-013-B2 did not activate RXR/LXR and RXR/RAR $\alpha$ heterodimers (Additional file 1A and B). Also CNX-013-B2 did not activate any of the PPAR isoforms, $\alpha, \delta$ or $\gamma$, in absence of RXR (Additional file 1C, D and E) while the PPAR $\alpha$, PPAR $\delta$ and PPAR $\gamma$ were activated by their respective agonists namely fenofibrate, GW501516 and rosiglitazone. This indicates that PPAR-pan activity (Table 1) is a result of activation of RXR and we therefore consider CNX-013-B2 as a selective rexinoid with PPAR-pan activity. Due to non-availability of specific reagents we were not able to demonstrate impact of CNX-013-B2 on activation of RXR/FXR and RXR/TR heterodimer complexes. We have not performed binding studies with any of the

\begin{tabular}{lll}
$\begin{array}{l}\text { Table } 1 \text { Potency towards RXR homedimers and } \\
\text { heterodimers }\end{array}$ \\
$\begin{array}{lll}\text { Nuclear } \\
\text { receptors }\end{array}$ & $\begin{array}{l}\text { CNX-013-B2 } \\
\text { EC }_{\mathbf{5 0}} \text { (nM) }\end{array}$ & Bexarotene \\
\hline RXRa & 48 & 18 \\
RXRß & 66 & ND \\
RXRY & 68 & ND \\
RXRa: PPARa & 159 & ND \\
RXRa: PPAR & 178 & ND \\
RXRa: PPARY & 196 & ND
\end{tabular}


nuclear receptors. In the RXR transfection assay Bexarotene (LG1069), a rexinoid approved for treating cutaneous T-cell lymphoma [30], displayed an EC50 of 18nM for activation of RXR $\alpha$ (Table 1). As the activation of the RXR/ PPAR heterodimers by Bexarotene, in the cotransfection assays, was similar to that of CNX-013-B2 at $1 \mu \mathrm{M}$ concentration (data not shown) we did not assess the EC50 towards individual RXR/PPAR isoform heterodimer complexes. However in contrast to CNX-013-B2 Bexarotene activated the RXR/LXR heterodimer complex (Additional file 1).

CNX-013-B2 significantly improves insulin sensitivity and glucose tolerance

To assess the impact of CNX-013-B2 on insulin sensitivity, oGTT, fasting and fed insulin levels and status of insulin signaling in muscle and adipose tissue were determined during the course of the study. In the OGTT performed in C57BL/6 J mice, the DIO control animals displayed significant glucose intolerance (Figure 1A), corresponding to a $75 \%$ increase in glucose $\mathrm{AUC}_{0-180}$, $(78134 \pm 3235$ vs $44596 \pm 1492 ; \mathrm{p}<0.001)$ when compared to lean control animals on chow diet (Figure 1C). When compared with DIO control, animals treated with CNX-013-B2 for 10 weeks were significantly less insulin resistant and displayed enhanced glucose tolerance (78134 \pm 3235 vs $58167 \pm 4854 ; \mathrm{p}<0.01)$ corresponding to a $25 \%$ decrease in glucose $\mathrm{AUC}_{0-180^{\prime}}$ (Figure $1 \mathrm{C}$ ). Plasma Insulin levels in the first 30' of oral glucose load was determined as another measure of insulin sensitivity. The DIO control animals were clearly insulin resistant and the $0-30$ ' insulin AUC $(72.2 \pm 17.05$ vs $19 \pm 1.93)$ was significantly higher $(\mathrm{p}<0.001)$ compared to lean control animals (Figure 1B inset). The first phase insulin peak at 10' time point in the DIO control animals was significantly higher $(\mathrm{p}<0.01)$ than that in lean control animals $(3.74 \pm 0.73 \mathrm{vs} 1.29 \pm 0.14 \mathrm{ng} / \mathrm{ml} ; \mathrm{p}<0.01)$. In comparison with DIO control animals in CNX-013-B2 treated animals the insulin peak at 10' time point was completely blunted $(1.3 \pm 0.18$ vs $3.74 \pm 0.73 \mathrm{ng} / \mathrm{ml} ; \mathrm{p}<0.01)$,

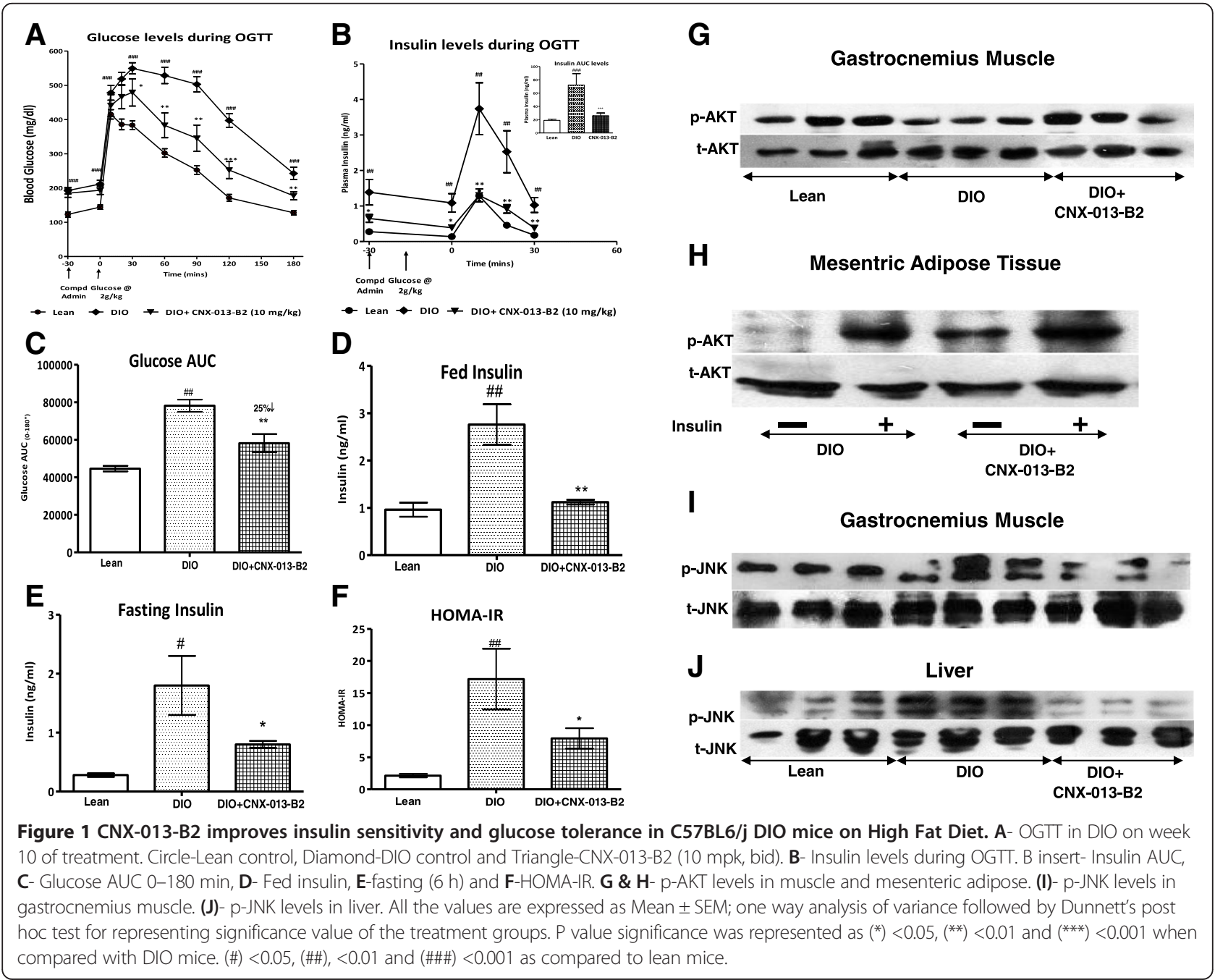


almost reaching levels observed in lean control animals (Figure 1B), resulting in a significant $73 \%$ reduction (Figure 1B inset) in the $0-30$ ' insulin AUC (72.2 \pm 17.05 vs $19 \pm 1.93)$. Even with reduced insulin secretion in the first 30' CNX-013-B2 treated animals displayed a $29 \%$ reduction in the $30-180$ ' glucose AUC (45728 $\pm 4630 \mathrm{vs}$ $64361 \pm 2943$; $\mathrm{p}<0.001)$ when compared with DIO control animals. Similarly CNX-013-B2 treated animals displayed a significant 60\% decrease (Figure 1D) in fed insulin $(1.12 \pm 0.05$ vs $2.76 \pm 0.43 \mathrm{ng} / \mathrm{ml} ; \mathrm{p}<0.01)$ levels and a $53 \%$ decrease (Figure 1E) in fasting insulin $(0.8 \pm$ 0.06 vs $1.8 \pm 0.4 \mathrm{ng} / \mathrm{ml} ; \mathrm{p}<0.05)$ as compared to DIO control at the end of the study. Accordingly the CNX-013-B2 treated animals showed a significant 55\% reduction in HOMA-IR indicating significant improvement in whole body insulin sensitivity (Figure $1 \mathrm{~F}$ ). It is well known that AKT phosphorylation is reduced under conditions of insulin resistance and immediately restored upon onset of insulin sensitivity. Improvement in the insulin sensitivity was further supported by increased p-AKT levels in muscle (Figure 1G) and mesenteric adipose tissue (Figure 1H). Also treatment resulted in reduced p-JNK levels in skeletal muscle and liver indicating CNX-013-B2 reduces metabolic stress and hence improves insulin sensitivity (Figure 1I \& J).

Treatment of ob/ob animals with CNX-013-B2 at $10 \mathrm{mg} / \mathrm{kg}$ for 4 weeks improved insulin sensitivity and glucose tolerance resulting in an $18 \%$ decrease in glucose AUC $(32464 \pm 944$ vs $26663 \pm 1222 ; \mathrm{p}<0.01)$ (Figure 2A and $\mathrm{B})$. However in these animals there was no decrease in either fasting or fed insulin levels (Figure $2 \mathrm{C}$ and $\mathrm{D}$ ) respectively. In liver a significant reduction in p-JNK levels suggests robust reduction in overall hepatocyte metabolic stress (Figure 2E). A significant increase in p-AKT level was observed in adipocytes from inguinal depot in treated animals indicating enhanced insulin signaling (Figure 2F). It can be concluded that treatment with CNX-013-B2 enhances insulin sensitivity and improves glucose tolerance in $\mathrm{ob} / \mathrm{ob}$ mice.

\section{CNX-013-B2 reduces serum glucose and lipid levels}

At the start of the treatment period, fasting plasma glucose (FPG) levels were $208.38 \mathrm{mg} / \mathrm{dl}$ in the DIO control animals, $206.1 \mathrm{mg} / \mathrm{dl}$ in the CNX-013-B2 group and 114.13 $\mathrm{mg} / \mathrm{dl}$ in the lean control animals on chow diet. After 3 weeks of dosing FPG levels started to decrease in the animals treated with CNX-013-B2 and reached a healthy and significant $14 \%$ decrease $(197 \pm 5$ vs $169 \pm 5 \mathrm{mg} / \mathrm{dl}$; $\mathrm{p}<0.01$ ) by the end of the treatment period (Figure 3A). At the start of the study fed glucose levels had increased considerably and reached $238 \pm 8 \mathrm{mg} / \mathrm{dl}$ in the animals designated as ob/ob control and $235 \pm 15 \mathrm{mg} / \mathrm{dl}$ in the animals designated for treatment with CNX-013-B2 at $10 \mathrm{mg} / \mathrm{kg}$. Compared to ob/ob control animals an acute and statistically significant $39 \%$ reduction in fed glucose levels $(208 \pm 26$ vs $125 \pm 3 \mathrm{mg} / \mathrm{dl} ; \mathrm{p}<0.001)$ was recorded after one week of treatment itself and this trend continued and reached a statistically significant $24 \%$ reduction $(196 \pm 3 \mathrm{vs} 149 \pm 4 \mathrm{mg} / \mathrm{dl} ; \mathrm{p}<0.001)$ at the end of 4 weeks (Figure 3B). After 8 weeks of high fat feeding, plasma triglyceride levels had reached $199 \mathrm{mg} / \mathrm{dl}$ in the DIO control group and $191.8 \mathrm{mg} / \mathrm{dl}$ in the group designated to be

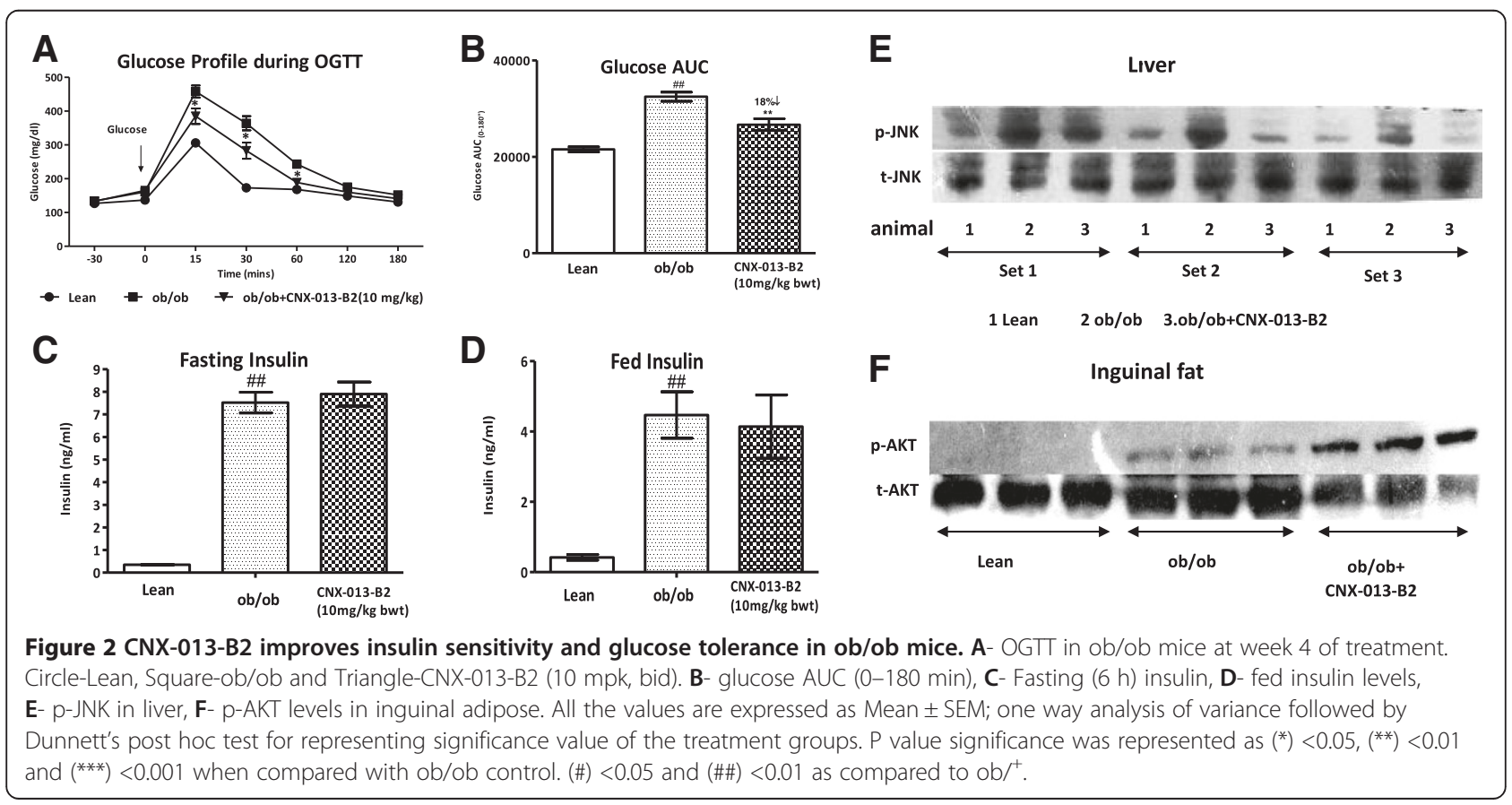



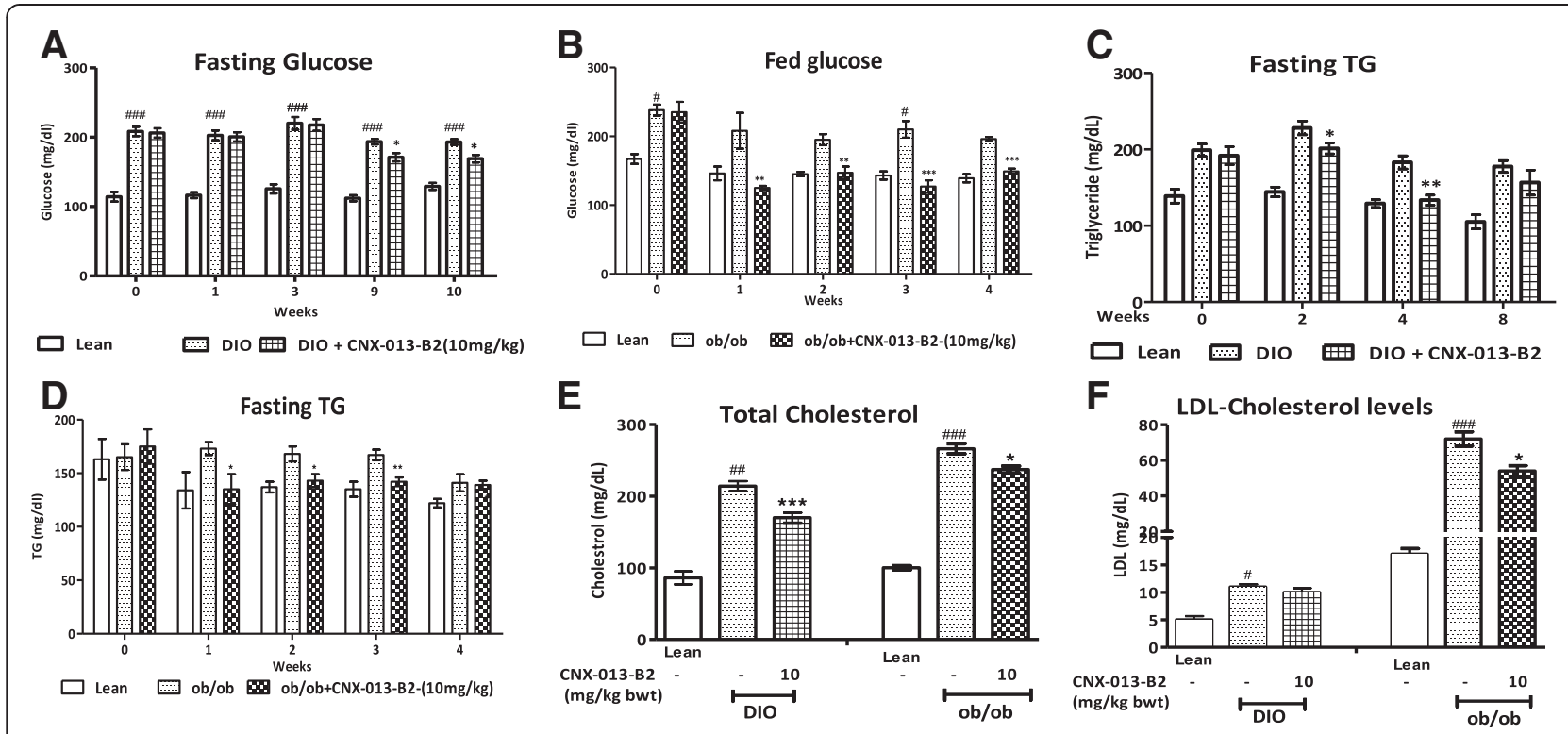

Figure 3 CNX-013-B2 reduces blood glucose and lipid levels. A- Fasting $(6 \mathrm{~h})$ glucose in DIO mice. B- Fed glucose in ob/ob mice. C- Fasting TG in DIO mice. D- Fasting TG in ob/ob mice. E- Total cholesterol and F-LDLc. All the values are expressed as Mean \pm SEM; one way analysis of variance followed by Dunnett's test for representing significance value of the treatment groups. P value significance was represented as $(*)<0.05$, $(* *)<0.01$ and $\left({ }^{* * *}\right)<0.001$ when compared with DIO control. $(\#)<0.05$ and $(\# \# \#)<0.001$ as compared to lean or ob/ ${ }^{+}$

treated with CNX-013-B2 while in the lean control animals on chow diet it was $138.75 \mathrm{mg} / \mathrm{dl}$. During the study circulating triglyceride levels remained consistently higher in the DIO control animals. Treatment with CNX013-B2 caused a significant decrease in serum TG levels (Figure 3C) by the 4th week ( $183 \pm 8$ vs $133 \pm 6 \mathrm{mg} / \mathrm{dl}$; $\mathrm{p}<0.01$ ) while in the ob/ob animals the decrease in serum TG levels was not statistically significant (Figure 3D). In comparison with DIO control animals, treatment with CNX-013-B2 significantly reduced serum total cholesterol $(214 \pm 8$ vs $170 \pm 7 \mathrm{mg} / \mathrm{dl} ; \mathrm{p}<0.001)$ in the fed state (Figure 3E) while the decrease in fasting LDL levels $(11 \pm 0.5 \mathrm{Vs} 10 \pm 0.6 \mathrm{mg} / \mathrm{dl}$ ) was non-significant (Figure 3F). When compared with control ob/ob animals, in CNX013-B2 treated animals both total cholesterol in the fed state $(266 \pm 7$ vs $230 \pm 5 \mathrm{mg} / \mathrm{dl} ; \mathrm{p}<0.05 ;)$ and fasting LDL-C (72 \pm 4 vs $54 \pm 3 \mathrm{mg} / \mathrm{dl}$; $\mathrm{p}<0.05)$ decreased significantly (Figure 3E \& F).

The reduction in serum glycerol and free fatty acids in both C57BL/6 J animals on DIO and in ob/ob mice was however statistically non-significant (Additional file 2A and $\mathrm{B})$.

\section{CNX-013-B2 has significant effect on body weight}

At the start of the study, the average body weight was $22 \mathrm{~g}, 36.41 \mathrm{~g}$ and $36 \mathrm{~g}$ in the lean control, DIO control group and in the CNX-013-B2 treatment group respectively. In the DIO control group, body weight increased from $36.41 \mathrm{~g}$ to $40.51 \mathrm{~g}$ during the 9 week study period. In contrast, beginning from the first week itself, treatment with CNX-013-B2 prevented any increase in body weight and instead a gradual decrease was observed all through the study and reached $33.43 \mathrm{~g}$ at the end of the treatment period. In effect a $7 \%$ decrease from basal body weight was recorded during the 9 weeks treatment (Figure 4A) and significant reductions in the absolute weight of inguinal (35\%), mesenteric (35\%) and epididymal (37\%) fat depots were observed (Figure 4B). It is important to note that there was no change in food intake in the treated animals (data not shown). While the adipocytes from the mesenteric depot showed a significant $(\mathrm{p}<0.01)$ decrease in size (Figure $4 \mathrm{C}$ ) a non-significant decrease in size was observed in the adipocytes from the inguinal depot (data not shown). The decrease in body weight of ob/ob animals was non-significant after 4 weeks of treatment (Figure 4D) and a longer treatment period is perhaps necessary to demonstrate the effect on body weight in this genetic background.

\section{CNX-013-B2 enhances non-shivering thermogenesis}

Basal body temperature was similar between lean control and DIO control animals. However, CNX-013-B2 treated animals recorded about $1^{\circ} \mathrm{C}$ higher temperature than DIO control animals $\left(37 \pm 0.3^{\circ} \mathrm{C}\right.$ vs $\left.36 \pm 0.4^{\circ} \mathrm{C}\right)$. But $15^{\prime}$ after shifting to a $4^{\circ} \mathrm{C}$ environment, rectal temperature dropped by $2^{\circ} \mathrm{C}$ in both the DIO control and the CNX-013-B2 treated animals. Subsequently in contrast to the steady decrease that was observed in the DIO control animals the CNX-013-B2 treated animals maintained their rectal temperature without any further decrease (Figure 4E). At 


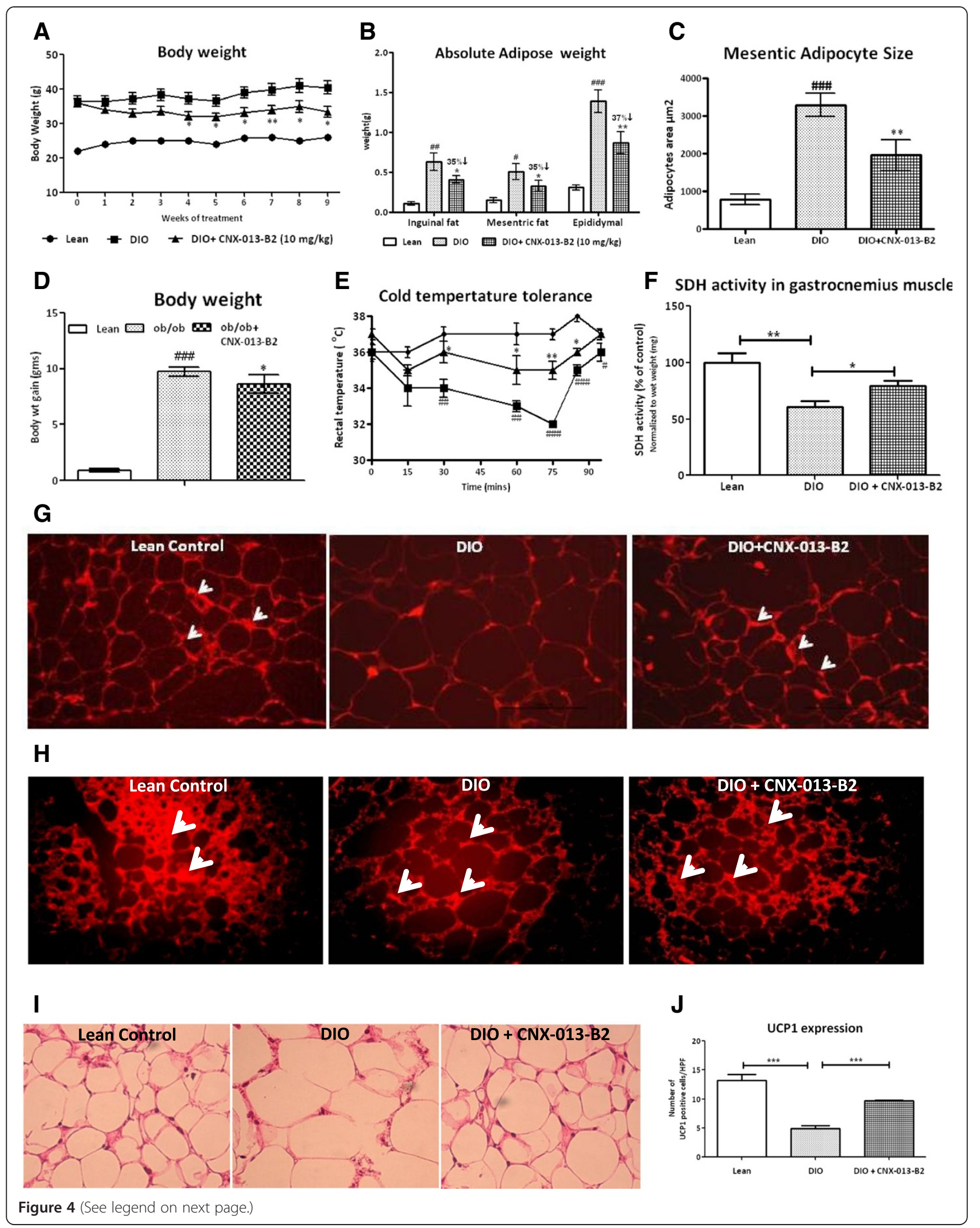


(See figure on previous page.)

Figure 4 CNX-013-B2 reduces body weight and enhances non-shivering thermogenesis. A- Body weight in DIO mice, B-Absolute adipose depot weight, C- mesenteric adipocyte size, D- Body weight gain in ob/ob mice, E-Cold temperature tolerance in DIO mice, $\mathbf{F}$ - SDH activity in gastrocnemius muscle of DIO mice, $\mathbf{G}$ and $\mathbf{H}-$ - UCPI expression levels in inguinal and brown adipocyte, I- H\&E of adipocytes and J-UCP1 quantification in inguinal adipocytes. All the values are expressed as Mean \pm SEM; one way analysis of variance followed by Dunnett's test for representing significance value of the treatment groups. P value significance was represented as $\left(^{*}\right)<0.05,(* *)<0.01$ and $\left(^{* *}\right)<0.001$ when compared with $\mathrm{DIO}$ control. (\#) $<0.05$, $(\# \#),<0.01$ and $(\# \# \#)<0.001$ as compared to lean or ob/ ${ }^{+}$.

the end of the 75' exposure body temperature dropped by $4^{\circ} \mathrm{C}$ in the DIO control animals and only by $2^{\circ} \mathrm{C}$ in the CNX-013-B2 treated animals. The CNX-013-B2 treated animals appeared to mount a strong adaptive thermogenesis in response to cold exposure. It is important to note that succinate dehydrogenase $(\mathrm{SDH})$ activity increased in gastrocnemius muscle (Figure $4 \mathrm{~F}$ ) and expression of UCP1 was significantly increased in both inguinal and brown fat of CNX-013-B2 treated animals (Figure 4G, H and J). Quantification of UCP1 expression indicated a $45 \%$ increase in the number of UCP1 positive cells in the inguinal white adipose tissue of CNX-013-B2 treated animals DIO animals (Figure 4J). We have not yet determined the possible mechanism of CNX-013-B2 mediated increase in UCP1 expression in inguinal fat and brown fat.

\section{CNX-013-B2 has beneficial effects in liver}

Treatment with CNX-013-B2 did not increase liver weight in either the ob/ob or in the DIO mice (Figure 5A). Further when compared with their respective controls there was no significant increase in either liver triglyceride (Figure 5B) or liver cholesterol (Figure 5C) content in either the ob/ob or the DIO mice. Histological analysis indicated that the periportal macro-vesicular steatosis, characterized by large lipid droplets and displaced nucleus, observed in the DIO control mice was completely ameliorated by treatment with CNX-013-B2 which instead resulted in pericentral micro-vesicular steatosis characterized by smaller lipid droplets and a centrally placed nucleus (Figure 5D, H\&E). Liver glycogen content that had significantly reduced in liver sections from DIO control appeared to have been reasonably restored in liver sections from CNX-013-B2 treated animals (Figure 5D, PAS).

\section{CNX-013-B2 reduces Cdk5 mediated Phosphorylation of PPARY}

It is reported that high fat feeding activates protein kinase cdk 5 which in turn phosphorylates PPARy at Serine 273 in adipose tissues [31]. In the DIO control mice phosphorylation of PPAR $\gamma$ at Serine 273 was markedly increased in adipocytes from both mesenteric and inguinal fat depots while in adipocytes from the same depots it was very significantly reduced in the CNX-013-B2 treated animals (Figure 6A, B). Serum adiponectin level, which was reduced in the DIO control animals, was significantly increased in the CNX-013-B2 treated animals (Figure 6C).
Treatment with CNX-013-B2 induces changes in gene expression in liver, adipose and muscle of $\mathrm{C} 57 \mathrm{BL} / 6 \mathrm{~J}$ and ob/ob mice

To identify the changes in gene expression induced by CNX-013-B2 mRNA expression of a set of genes, that are specific targets of nuclear receptors and are involved in glucose and fat metabolism, was assessed in liver, muscle and adipose from treated animals (Table 2). Treatment with CNX-013-B2 enhanced expression of genes that are reported to be transcribed by RXR/PPAR $\alpha$, RXR/PPAR $\delta$ and RXR/PPAR $\gamma$ and this was in agreement with the result obtained in cotransfection assays (Table 1). However an increase in expression of genes reported to be transcribed by RXR/LXR heterodimer, in contrast to data from cotransfection assays, was observed in the tissues. While this data can serve as an indirect evidence of activation of RXR/LXR in vivo the specific gene expression changes could have been induced by different and overlapping pathways. In absence of data from cotransfection assays we are unable to state if the observed modulation of expression of genes transcribed by RXR/FXR and RXR/ TR is a direct impact of CNX-013-B2 or is due to different and overlapping pathways. Treatment for either a short duration of 4 or a longer duration of 8 weeks appeared to induce similar changes in gene expression irrespective of the genetic background and nature of diet (Figures 7 and 8).

In ileum CNX-013-B2 significantly reduced expression of iBABP (intestinal Bile Acid Binding Protein) involved in intestinal bile acid binding [46] and NPC1L1, critical for intestinal cholesterol absorption [47].

In addition CNX-013-B2 also increased mRNA levels of thyroid hormone receptor $\beta$ (THRB) (Figure 7A:f), and decreased expression of apoCIII (apolipoprotein CIII) in liver, increased expression of DIO2 (De-iodinase 2) and SREBP1c (Figures 7D: $c$ and 8C: $d$ ) in muscle.

\section{Discussion}

RXR is often considered 'sui generis' owing to its ability to heterodimerize and modulate several other members of the nuclear receptors family. In this report we describe the biological characterisation of CNX-013-B2, a heterodimer selective rexinoid that has been designed, synthesized and developed by Connexios Life Sciences to treat various risk factors of the metabolic syndrome. CNX-013-B2 has ideal pharmacokinetic properties that 


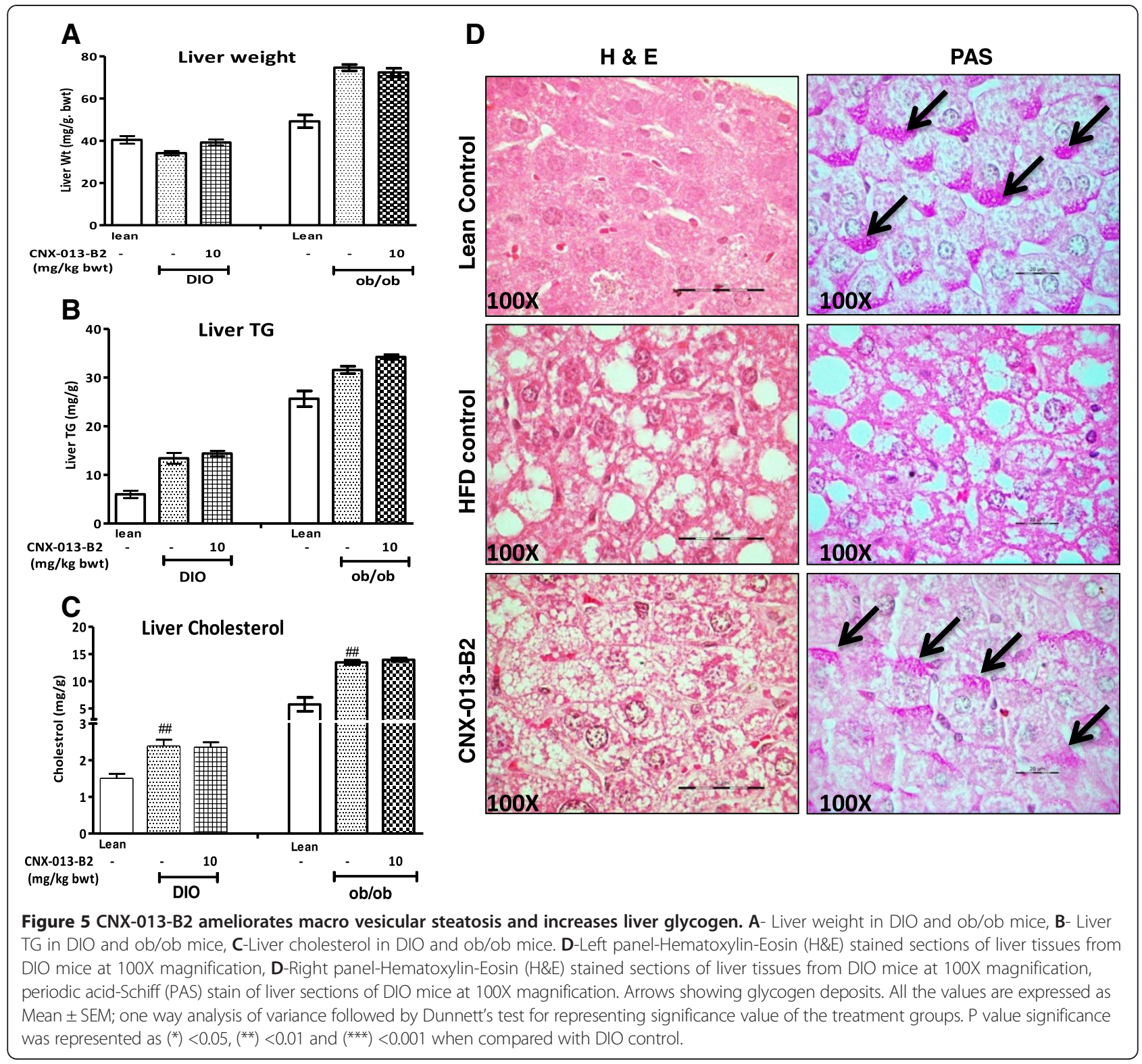

ensure good distribution specifically into muscle, adipose and liver with a serum half-life of 4-6 hrs in rodents (data not shown). Importantly treatment of mice for 10 weeks did not cause hypertriglyceridemia (Figure $3 \mathrm{C}$ and D) or ectopic fat accumulation (Figure 5B; Additional file 2D) or hepatomegaly (Figure $5 \mathrm{~A}$ ) or increase in body weight (Figure 4A, 4D).

In mouse models relevant to obesity and type 2 diabetes, such as ob/ob and C57BL/6 J DIO mice on high fat diet (HFD), treatment with CNX-013-B2 resulted in significant improvement in insulin sensitivity, control of fed and fasting glucose, fed and fasting triglyceride and cholesterol, a reduction in adiposity and body weight gain. The observed whole body insulin sensitivity (Figures 1F, 2E) can be attributed to the peripheral insulin sensitization by $\mathrm{CNX}-013-\mathrm{B} 2$ and similar improvements in insulin sensitivity have been reported earlier for RXR agonists $[48,49]$. There was a significant reduction of p-JNK levels (Figures 1I, 2F), a known mediator of free fatty acids [50] and inflammation [51] induced insulin resistance and a marker of cellular metabolic stress [52]. This coupled with increased p-AKT levels (Figures 1G, $1 \mathrm{H}, 2 \mathrm{G})$ suggested that treatment with CNX-013-B2 reduced cellular stress and consequently enhanced insulin sensitivity in liver, adipose and muscle. Treatment with CNX-013-B2 ameliorated macrovescicular steatosis in liver (Figure 5D H\&E), reduced muscle triglyceride content (Additional file 2D) and also reduced adipose hypertrophy (Figure 4B and C), thus leading to improvement in insulin sensitivity [53]. Such a strong reduction 


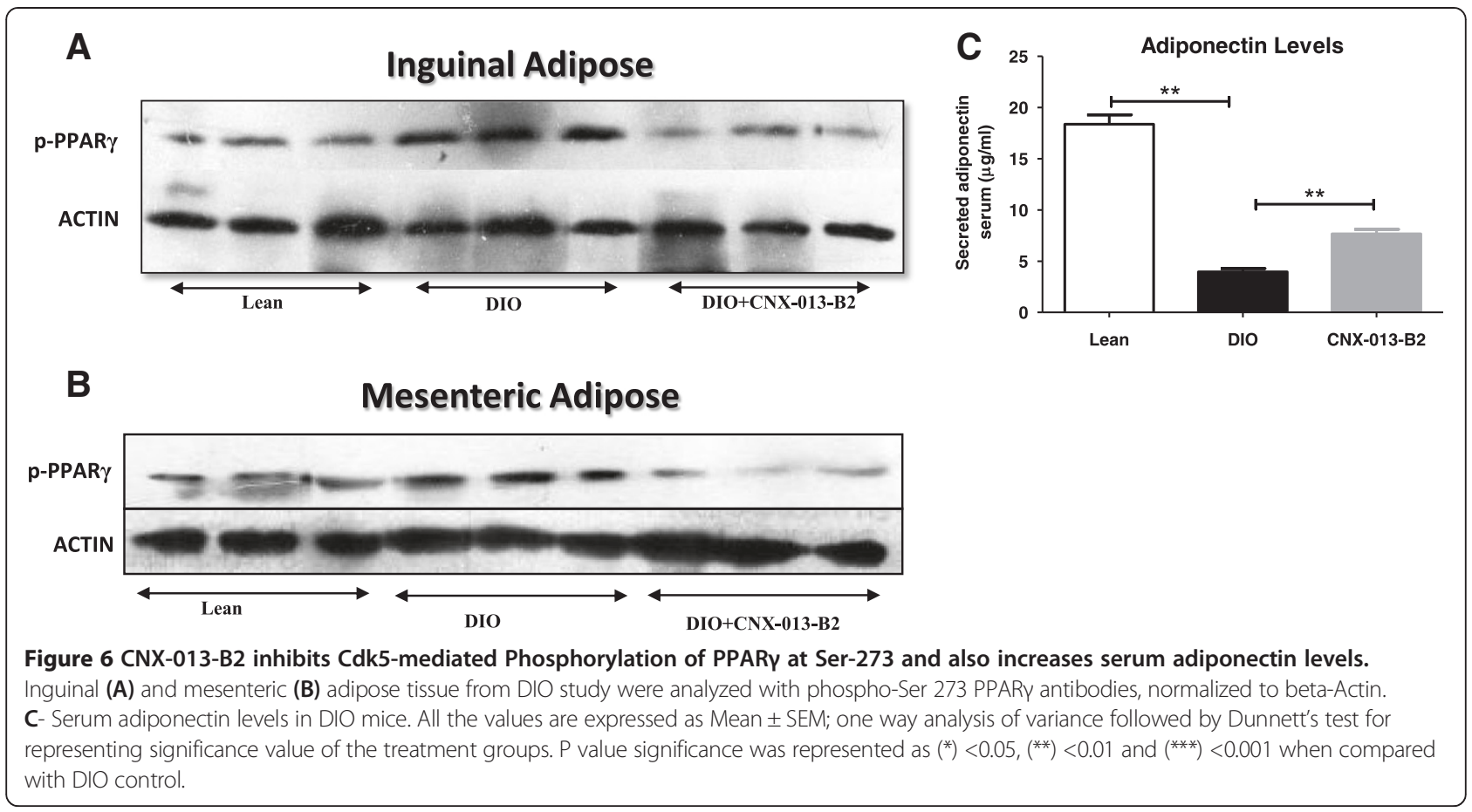

in insulin resistance perhaps, explains the steep reduction in the early phase insulin secretion peak at 10 ' time point and $0-30$ ' insulin AUC during OGTT performed in the DIO mice (Figure 1B) and the observed improvement in glucose tolerance in ob/ob mouse model after just 4 weeks of treatment (Figure 2A). Since both fasting and fed insulin levels were not measured early on in this study we are unable to state if the onset of improvement in insulin sensitivity preceded the reduction in fasting glucose levels.
In liver, gene expression profile suggests that a significant part of the pharmacological effect could be due to modulation of RXR/PPAR $\alpha$, RXR/LXR, RXR/THR and RXR/FXR heterodimer complexes. A previous study under similar conditions [54] reported that combined treatment with a PPAR $\alpha$ agonist, fenofibrate, and an LXR agonist, T0901317, alleviated insulin resistance and improved glucose tolerance but dramatically exacerbated hepatic steatosis. It is important to note that in CNX-013-B2 treated animals there was no increase in liver triglyceride content

Table 2 Specific target genes of nuclear receptors involved in glucose and fat metabolism

\begin{tabular}{|c|c|c|c|c|}
\hline Organ & Heterodimer & Gene & Function & Ref \\
\hline \multirow[t]{8}{*}{ Liver } & RXR/PPARa & ABCB4 & Biliary phosphotidyl choline secretion & {$[32,33]$} \\
\hline & & ApoAll & Constituent of HDL-C & [34] \\
\hline & & ACOX1 & Peroxisomal fatty acid oxidation & [35] \\
\hline & $\mathrm{RXR} / \mathrm{LXR}$ & SREBP1C & Regulation of enzymes of fatty acid synthesis & [36] \\
\hline & & SCD1 & Palmitic to palmitoleic and stearic to oleic acid & [37] \\
\hline & & FASN & De novo synthesis of fatty acids & [38] \\
\hline & & THRSP & Lipogenesis & [39] \\
\hline & & ABCG5/ABCG8 & Biliary secretion of cholesterol and phytosterols & {$[40]$} \\
\hline \multirow[t]{4}{*}{ Adipose } & PPARY & SCD1 & Palmitic to palmitoleic and stearic to oleic acid & [41] \\
\hline & LXR & PPARY & Adipogenesis & [42] \\
\hline & & SREBP1C & Regulation of enzymes of fatty acid synthesis & [42] \\
\hline & & SCD1 & Palmitic to palmitoleic and stearic to oleic acid & [43] \\
\hline \multirow[t]{2}{*}{ Muscle } & PPAR & PDK4 & Fatty acid oxidation & [44] \\
\hline & & UCP3 & Fatty acid oxidation and oxidative stress & [45] \\
\hline
\end{tabular}




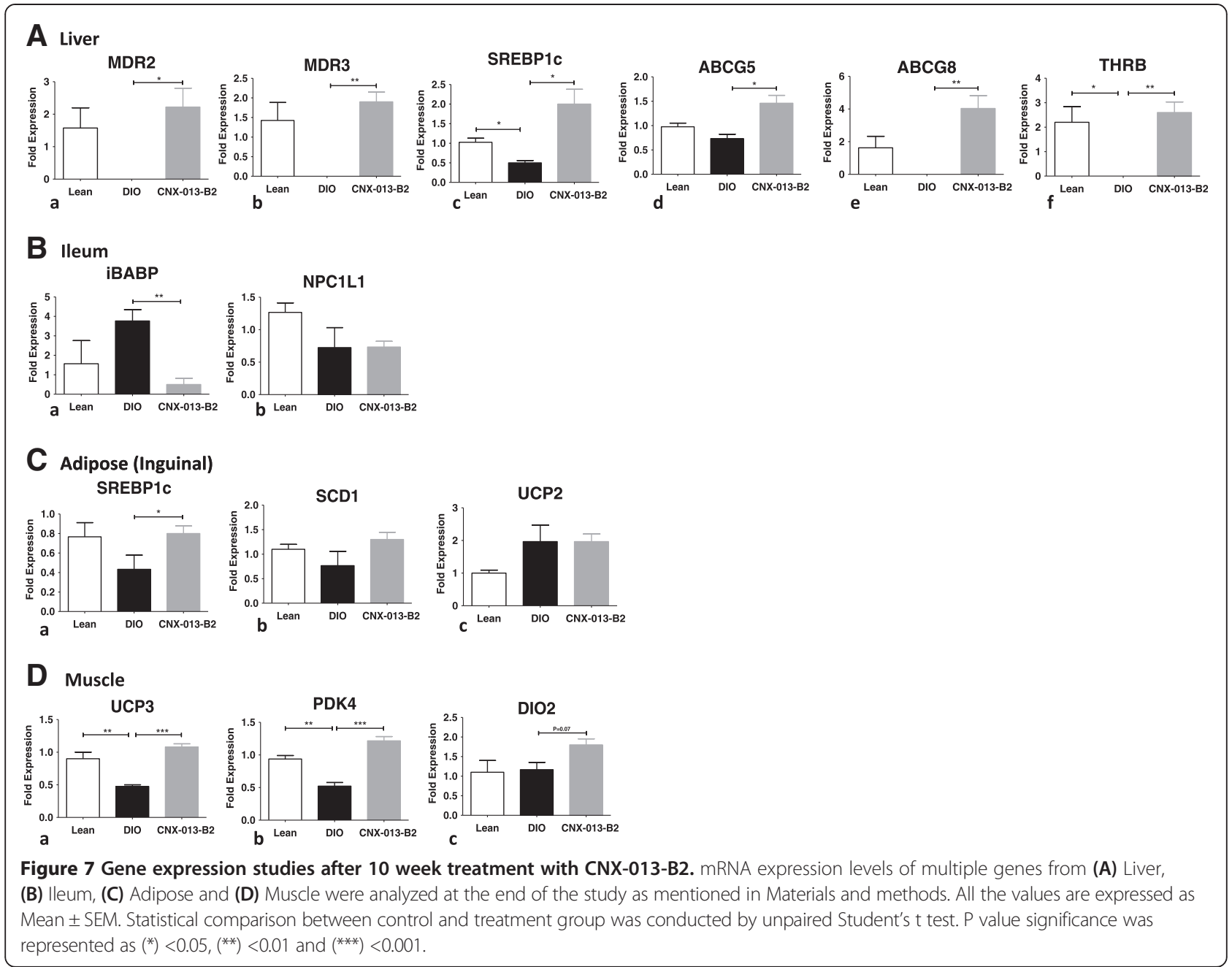

in spite of a significant increase in expression of RXR/ PPAR $\alpha$ and RXR/LXR target lipogenic genes, SREBP1c, SCD1 and FASN $[36,55,56]$. In absence of biochemical data such as oxygen consumption by the animals in the study our attempt to explain the lack of increase in liver triglyceride levels in both DIO on HFD and ob/ob upon treatment with CNX-013-B2 relies mainly on gene expression analysis, weights of adipose depots especially in the DIO mice and serum FFA, TG and glycerol levels. There was an appreciable decrease in weight of adipose depots especially in the DIO mice on HFD (Figure 4B) and yet there was no increase in serum free fatty acid or serum glycerol levels (Additional file 2). Contrary to gene expression profile suggesting increased fatty acid synthesis in liver of CNX-013-B2 treated mice, the DIO mice display amelioration of macrovesicular steatosis (Figure 5D) and in ob/ob mice there is no increase in liver triglyceride levels (Figure 5B). However gene expression profile especially in the muscle and adipose (Figures 7 and 8 ) suggests enhanced fatty acid oxidation. In absence of additional data we can perhaps state that an increase in fatty acid oxidation in the periphery, including adipose and muscle, is preventing triglyceride accumulation in the livers of $\mathrm{CNX}$ 013-B2 treated animals.

Further the role of RXR-PPAR $\alpha$ and RXR-LXR heterodimers in mediating the effect of CNX-013-B2 is substantiated by the observed increase in liver glycogen content (Figure 5D) as it has been previously shown in rodent models, that both PPAR $\alpha$ and LXR can regulate glycogen synthesis and flux in liver $[57,58]$.

In adipocytes the insulin sensitizing effects of CNX013-B2 seems to be mediated by both RXR/PPAR $\gamma$ and RXR/LXR heterodimer complex which is a known insulin sensitizer in adipocytes $[59,60]$.

In obesity cytokine and high fat diet induced CDK5 mediated phosphorylation of PPARY is reported to dysregulate expression of a number of genes including adiponectin [31]. A non-agonist PPARY ligand, SR1664, not only blocked CDK5 mediated phosphorylation but also displayed anti-diabetic activity without causing fluid 


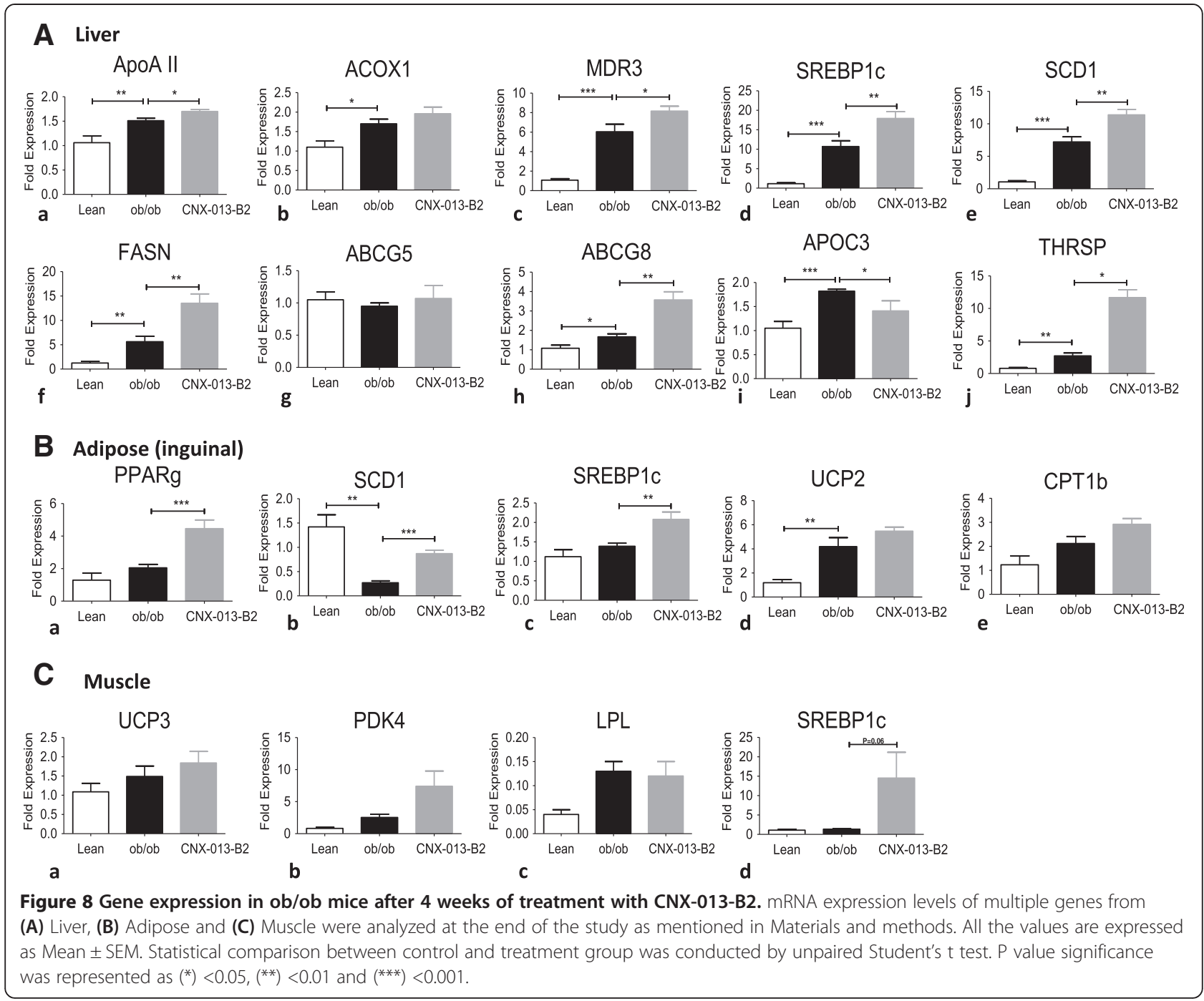

retention and weight gain [61]. Treatment with CNX-013B2 also inhibited CDK5 mediated phosphorylation of PPAR $\gamma$ in both mesenteric and inguinal depots and reduced weight of various adipose depots (Figure 6A \& B). The enhanced p-AKT levels in mesenteric and inguinal adipocytes and reduced lipolysis suggest that CNX-013-B2 reduced high fat diet induced inflammation leading to better glucose and lipid tolerance.

Among the factors that are implicated in the development of brown adipose tissue, RXR $\alpha / \gamma$ [62], PPAR $\alpha$ [63] and PPARY [64] are also reported to regulate mRNA expression of UCP1 gene. It therefore appears possible that activation of RXR $\alpha / \gamma$, PPAR $\alpha$ and PPAR $\gamma$ by CNX-013-B2 could be one of the reasons for the enhanced UCP1 protein expression in the BAT of treated animals (Figure $4 \mathrm{H}$ ). There are a host of factors, that include transcriptional regulators as well as proteins and secreted mediators, that are reported to regulate browning of white adipose tissue and it is beyond the scope of this article to enumerate role of each of them. However one of the key regulators of browning of white adipose tissue that can be activated by CNX-013-B2 happens to be PPAR $\gamma$ [64]. The browning of inguinal WAT in the DIO mice on HFD appears to be a net result of the regulation of the various pro- and antibrowning factors by the modulation of RXR and its heterodimer partners by CNX-013-B2. Additional experiments are necessary to delineate the mechanism of browning of inguinal WAT by CNX-013-B2.

The activation of RXR/PPAR $\delta$ in muscle by CNX-013-B2 and increased mRNA expression of UCP3 (Figure 8C:a) could be one of the reasons for the protection from high fat-induced insulin resistance and obesity $[45,65]$. It is well known that UCP3 enhances mitochondrial fatty acid oxidation [66] while also decreasing mitochondrial ROS generation [67] and this can perhaps explain the improvement in muscle p-AKT levels (Figure 1G) and succinate 
dehydrogenase activity (Figure 4F). Succinate dehydrogenase (SDH) activity is considered as an indicator of muscle oxidative capacity [68] and expression of genes involved in oxidative metabolism, including succinate dehydrogenase $\mathrm{B}$, is reported to be reduced in skeletal muscle of diabetes mellitus patients [69]. The increase in SDH activity in treated animals indicates that the oxidative capacity of muscle is significantly modulated by treatment with CNX013-B2.

In a separate study under progress we have observed an increase in exercise capacity, in terms of treadmill running, of C57BL/6 J mice on HFD after treatment with CNX-013-B2 for 5 weeks (unpublished observations). It will be interesting to examine if activation of RXR/LXR and RXR/PPAR $\delta$ by CNX-013-B2 in muscle can impact reprogramming of muscle fibers similar to PPAR $\delta$ overexpression in muscle [45]. Also increase in expression of DIO-2 and UCP3 in muscle [70] and THRB and THRSP [71] in liver suggest that pharmacological effect of CNX-013-B2, observed in this study, could also be due to activation of thyroid hormone signaling in muscle and liver. The expression of genes such as MDR3, ABCG5/8 (in liver) and BBABP and NPC1L1 in intestine suggests modulation of enterohepatic circulation of bile acids leading to inhibition of dietary cholesterol absorption and such an effect has previously been reported for the RXR agonist Bexarotene [72]. Even though the reduction in serum fed cholesterol levels is statistically significant further studies will be necessary to establish that CNX-013-B2 treatment can cause marked inhibition of dietary cholesterol absorption.

The forgoing results provide a pharmacological proof of concept for a selective small molecule-based rexinoid, CNX-013-B2, that combines the lipid lowering effects of PPAR $\alpha$ PPAR $\delta$ and LXR, insulin sensitizing and glucose lowering effects of PPAR $\alpha / \gamma$, LXR and THRB and energy uncoupling effects of PPAR $\delta$ with potential to reduce weight gain. We demonstrate that a coordinated modulation of several nuclear receptors and multiple molecular pathways controlling intermediary metabolism in liver, adipose and muscle has the potential to provide excellent control of metabolic parameters which can address multiple risk factors of the metabolic syndrome.

\section{Conclusions}

In summary, CNX-013-B2 is a selective and orally bioavailable rexinoid. Pharmacological activation of RXR with CNX-013-B2 can give strong glycemic and lipid control, improve insulin sensitivity without increasing body weight, enhance muscle oxidative capacity and function and has a potential to control hepatic steatosis. CNX-013-B2 does not cause hypertriglyceridemia, hepatomegaly and body weight gain. Further preclinical safety and toxicity studies are in progress.

\section{Additional files}

Additional file 1: CNX-013-B2 is a selective rexinoid. CNX-013-B2 does not activate $h R X R a / h L X R a$ and $h R X R a / h R A R a$ heterodimers (A \& B). Also CNX-013-B2 does not activate PPAR isoforms alone ( $C$ - D). The details of the methods are mentioned in the Materials and methods.

Additional file 2: CNX-013-B2 has minimal impact on serum and tissue lipid levels. After study termination, serum glycerol, free fatty acids and muscle TG were analyzed as mentioned in the Materials and methods. All the values are expressed as Mean \pm SEM; one way analysis of variance followed by Dunnett's test for representing significance value of the treatment groups. $P$ value significance was represented as $\left(^{*}\right)<0.05,\left(^{* *}\right)<0.01$ and $\left({ }^{* *}\right)<0.001$.

\section{Abbreviations}

OGTT: Oral glucose tolerance test; HFD: High fat diet; T2DM: Type 2 Diabetes Mellitus; DIO: Diet induced obesity; UCP1: Uncoupling protein 1; SREBP1c: Sterol Regulatory Element-Binding Protein 1c; TG: Triglyceride; LDL: Low-density lipoprotein; FFA: Free fatty acid; NASH: Nonalcoholic steatohepatitis; PBS: Phosphate buffered saline; HOMA-IR: Homeostasis model assessment-estimated insulin resistance.

\section{Competing interests}

All the authors are employees of Connexios Life Sciences Pvt Ltd and declare that they have no competing interests.

\section{Authors' contributions}

BMR, JS, SV MNL, SY, SKC, TLP, CH, ASG, SP, BSN, and PMP carried out experiments; MKS, MKV, AD, AMO, YM, MW, BPS and MRJ planned/executed the study, analyzed data. MW, BPS and MRJ wrote the manuscript. All authors read and approved the final manuscript.

Received: 22 July 2014 Accepted: 6 August 2014

Published: 12 August 2014

\section{References}

1. Grundy SM, Hansen B, Smith SC Jr, Cleeman JI, Kahn RA, American Heart A National Heart L, Blood I, American Diabetes A: Clinical management of metabolic syndrome: report of the American Heart Association/National Heart, Lung, and Blood Institute/American Diabetes Association conference on scientific issues related to management. Circulation 2004, 109:551-556.

2. Inoue I, Goto S, Mizotani K, Awata T, Mastunaga T, Kawai S, Nakajima T, Hokari S, Komoda T, Katayama S: Lipophilic HMG-CoA reductase inhibitor has an anti-inflammatory effect: reduction of MRNA levels for interleukin-1 beta, interleukin-6, cyclooxygenase-2, and p22phox by regulation of peroxisome proliferator-activated receptor alpha (PPARalpha) in primary endothelial cells. Life Sci 2000, 67:863-876.

3. Calkin AC, Giunti S, Jandeleit-Dahm KA, Allen TJ, Cooper ME, Thomas MC: PPAR-alpha and -gamma agonists attenuate diabetic kidney disease in the apolipoprotein E knockout mouse. Nephrol Dial Transplant 2006, 21:2399-2405

4. Calkin AC, Forbes JM, Smith CM, Lassila M, Cooper ME, Jandeleit-Dahm KA, Allen TJ: Rosiglitazone attenuates atherosclerosis in a model of insulin insufficiency independent of its metabolic effects. Arterioscler Thromb Vasc Biol 2005, 25:1903-1909.

5. Marx N, Walcher D, Ivanova N, Rautzenberg K, Jung A, Friedl R, Hombach V, de Caterina R, Basta G, Wautier MP, Wautiers JL: Thiazolidinediones reduce endothelial expression of receptors for advanced glycation end products. Diabetes 2004, 53:2662-2668.

6. Marx N, Froehlich J, Siam L, Ittner J, Wierse G, Schmidt A, Scharnagl H, Hombach V, Koenig W: Antidiabetic PPAR gamma-activator rosiglitazone reduces MMP-9 serum levels in type 2 diabetic patients with coronary artery disease. Arterioscler Thromb Vasc Biol 2003, 23:283-288.

7. Olefsky JM: Treatment of insulin resistance with peroxisome proliferatoractivated receptor gamma agonists. J Clin Invest 2000, 106:467-472.

8. Hotamisligil GS: Inflammation and metabolic disorders. Nature 2006, 444:860-867. 
9. Bortolini M, Wright MB, Bopst M, Balas B: Examining the safety of PPAR agonists - current trends and future prospects. Expert Opin Drug Saf 2013, 12(1):65-79.

10. Fruchart JC, Staels B, Duriez P: The role of fibric acids in atherosclerosis. Curr Atheroscler Rep 2001, 3:83-92.

11. Staels B, Fruchart JC: Therapeutic roles of peroxisome proliferatoractivated receptor agonists. Diabetes 2005, 54:2460-2470.

12. Israelian-Konaraki Z, Reaven PD: Peroxisome proliferator-activated receptor-alpha and atherosclerosis: from basic mechanisms to clinical implications. Cardiology 2005, 103:1-9.

13. Barish GD, Narkar VA, Evans RM: PPAR delta: a dagger in the heart of the metabolic syndrome. J Clin Invest 2006, 116:590-597.

14. Higgins LS, Depaoli AM: Selective peroxisome proliferator-activated receptor gamma (PPARgamma) modulation as a strategy for safer therapeutic PPARgamma activation. Am J Clin Nutr 2010, 91(1):267S-272S.

15. Dunn FL, Higgins LS, Fredrickson J, DePaoli AM, group INTs: Selective modulation of PPARgamma activity can lower plasma glucose without typical thiazolidinedione side-effects in patients with Type 2 diabetes. J Diabetes Complications 2011, 25:151-158.

16. Evans JL, Lin JJ, Goldfine ID: Novel approach to treat insulin resistance, type 2 diabetes, and the metabolic syndrome: simultaneous activation of PPARalpha, PPARgamma, and PPARdelta. Curr Diabetes Rev 2005, 1:299-307.

17. Tenenbaum A, Fisman EZ: Balanced pan-PPAR activator bezafibrate in combination with statin: comprehensive lipids control and diabetes prevention? Cardiovasc Diabetol 2012, 11:140

18. Cao G, Liang Y, Broderick CL, Oldham BA, Beyer TP, Schmidt RJ, Zhang Y, Stayrook KR, Suen C, Otto KA, Miller AR, Dai J, Foxworthy P, Gao H, Ryan TP, Jiang XC, Burris TP, Eacho PI, Etgen GJ: Antidiabetic action of a liver $\mathrm{x}$ receptor agonist mediated by inhibition of hepatic gluconeogenesis. J Biol Chem 2003, 278:1131-1136.

19. Yuan C, Lin JZ, Sieglaff DH, Ayers SD, Denoto-Reynolds F, Baxter JD, Webb P: Identical gene regulation patterns of T3 and selective thyroid hormone receptor modulator GC-1. Endocrinology 2012, 153:501-511.

20. Lefebvre $P$, Benomar $Y$, Staels B: Retinoid $X$ receptors: common heterodimerization partners with distinct functions. Trends Endocrinol Metab 2010, 21(11):676-683.

21. Kreze $W$, Dupé $V$, Mark $M$, Dierich $A$, Kastner $P$, Chambon P: RXR gamma null mice are apparently normal and compound RXR alpha +/-/RXR beta -/-/RXR gamma -/-mutant mice are viable. Proc Natl Acad SCi U S A 1996, 93(17):9010-9014.

22. Wan YJ, An D, Cai Y, Repa JJ, Hung-Po Chen T, Flores M, Postic C, Magnuson MA, Chen J, Chien KR, French S, Mangelsdorf DJ, Sucov HM: Hepatocytespecific mutation establishes retinoid $\mathrm{X}$ receptor alpha as a heterodimeric integrator of multiple physiological processes in the liver. Mol Cell Biol 2000, 20(12):4436-4444.

23. He Y, Gong L, Fang Y, Zhan Q, Liu HX, Lu Y, Guo GL, Lehman-McKeeman L, Fang J, Wan YJ: The role of retinoic acid in hepatic lipid homeostasis defined by genomic binding and transcriptome profiling. BMC Genomics 2013, 14:575-586.

24. Imai T, Jiang $M$, Chambon $P$, Metzger D: Impaired adipogenesis and lipolysis in the mouse upon selective ablation of the retinoid $X$ receptor alpha mediated by a tamoxifen-inducible chimeric Cre recombinase (Cre-ERT2) in adipocytes. Proc Natl Acad Sci U S A 2001, 98:224-228.

25. Szanto A, Narkar V, Shen Q, Uray IP, Davies PJ, Nagy L: Retinoid X receptors: X-ploring their (patho)physiological functions. Cell Death Differ 2004, 11(Suppl 2):S126-S143.

26. Mukherjee R, Strasser J, Jow L, Hoener P, Paterniti JR Jr, Heyman RA: RXR agonists activate PPARalpha-inducible genes, lower triglycerides, and raise HDL levels in vivo. Arterioscler Thromb Vasc Biol 1998, 18:272-276.

27. Claudel T, Leibowitz MD, Fiévet C, Tailleux A, Wagner B, Repa JJ, Torpier G, Lobaccaro JM, Paterniti JR, Mangelsdorf DJ, Heyman RA, Auwerx J: Reduction of atherosclerosis in apolipoprotein $\mathrm{E}$ knockout mice by activation of the retinoid X receptor. Proc Natl Acad Sci U S A 2001, 98:2610-2615

28. Mukherjee R, Davies PJ, Crombie DL, Bischoff ED, Cesario RM, Jow L, Hamann LG, Boehm MF, Mondon CE, Nadzan AM, Paterniti JR Jr, Heyman $R A$ : Sensitization of diabetic and obese mice to insulin by retinoid $X$ receptor agonists. Nature 1997, 386:407-410.

29. Miller VA, Benedetti FM, Rigas JR, Verret AL, Pfister DG, Straus D, Kris MG, Crisp M, Heyman R, Loewen GR, Truglia JA, Warrell RP Jr: Initial clinical trial of a selective retinoid X receptor ligand, LGD1069. J Clin Oncol 1997, 15:790-795.

30. Pinaire JA, Reifel-Miller A: Therapeutic potential of retinoid $x$ receptor modulators for the treatment of the metabolic syndrome. PPAR Res 2007, 2007:94156

31. Choi JH, Banks AS, Estall JL, Kajimura S, Boström P, Laznik D, Ruas JL, Chalmers MJ, Kamenecka TM, Blüher M, Griffin PR, Spiegelman BM: Antidiabetic drugs inhibit obesity-linked phosphorylation of PPARgamma by Cdk5. Nature 2010, 466:451-456.

32. Kok T, Bloks WW, Wolters H, Havinga R, Jansen PL, Staels B, Kuipers F: Peroxisome proliferator-activated receptor alpha (PPARalpha)-mediated regulation of multidrug resistance 2 ( $M d r 2$ ) expression and function in mice. Biochem J 2003, 369:539-547.

33. Ghonem NS, Ananthanarayanan M, Soroka CJ, Boyer JL: Peroxisome proliferator-activated receptor alpha activates human multidrug resistance transporter 3/ATP-binding cassette protein subfamily B4 transcription and increases rat biliary phosphatidylcholine secretion. Hepatology 2014, 59:1030-1042.

34. Vu-Dac N, Schoonjans K, Kosykh V, Dallongeville J, Fruchart JC, Staels B, Auwerx J: Fibrates increase human apolipoprotein A-II expression through activation of the peroxisome proliferator-activated receptor. J Clin Invest 1995, 96:741-750.

35. Issemann I, Prince RA, Tugwood JD, Green S: The peroxisome proliferatoractivated receptor:retinoid $\mathrm{X}$ receptor heterodimer is activated by fatty acids and fibrate hypolipidaemic drugs. J Mol Endocrinol 1993, 11:37-47.

36. Pawar A, Botolin D, Mangelsdorf DJ, Jump DB: The role of liver X receptoralpha in the fatty acid regulation of hepatic gene expression. $J$ Biol Chem 2003, 278:40736-40743.

37. Basciano H, Miller A, Baker C, Naples M, Adeli K: LXRalpha activation perturbs hepatic insulin signaling and stimulates production of apolipoprotein B-containing lipoproteins. Am J Physiol Gastrointest Liver Physiol 2009, 297:G323-G332

38. Schultz JR, Tu H, Luk A, Repa JJ, Medina JC, Li L, Schwendner S, Wang S, Thoolen M, Mangelsdorf DJ, Lustig KD, Shan B: Role of LXRs in control of lipogenesis. Genes Dev 2000, 14:2831-2838.

39. Wu J, Wang C, Li S, Li S, Wang W, Li J, Chi Y, Yang H, Kong X, Zhou Y, Dong C, Wang F, Xu G, Yang J, Gustafsson JÅ, Guan Y: Thyroid hormoneresponsive SPOT 14 homolog promotes hepatic lipogenesis, and its expression is regulated by liver $\mathrm{X}$ receptor alpha through a sterol regulatory element-binding protein 1c-dependent mechanism in mice. Hepatology 2013, 58:617-628.

40. Yu XH, Qian K, Jiang N, Zheng XL, Cayabyab FS, Tang CK: ABCG5/ABCG8 in cholesterol excretion and atherosclerosis. Clin Chim Acta 2014, 428:82-88.

41. Yao-Borengasser A, Rassouli N, Varma V, Bodles AM, Rasouli N, Unal R, Phanavanh B, Ranganathan G, McGehee RE Jr, Kern PA: Stearoyl-coenzyme A desaturase 1 gene expression increases after pioglitazone treatment and is associated with peroxisomal proliferator-activated receptorgamma responsiveness. J Clin Endocrinol Metab 2008, 93:4431-4439.

42. Seo JB, Moon HM, Kim WS, Lee YS, Jeong HW, Yoo EJ, Ham J, Kang H, Park MG, Steffensen KR, Stulnig TM, Gustafsson JA, Park SD, Kim JB: Activated liver $X$ receptors stimulate adipocyte differentiation through induction of peroxisome proliferator-activated receptor gamma expression. Mol Cell Biol 2004, 24:3430-3444.

43. Darimont C, Avanti O, Zbinden I, Leone-Vautravers P, Mansourian R, Giusti V, Mace K: Liver $X$ receptor preferentially activates de novo lipogenesis in human preadipocytes. Biochimie 2006, 88:309-318.

44. Kramer DK, Al-Khalili L, Guigas B, Leng Y, Garcia-Roves PM, Krook A: Role of AMP kinase and PPARdelta in the regulation of lipid and glucose metabolism in human skeletal muscle. J Biol Chem 2007, 282:19313-19320.

45. Wang YX, Zhang CL, Yu RT, Cho HK, Nelson MC, Bayuga-Ocampo CR, Ham J, Kang H, Evans RM: Regulation of muscle fiber type and running endurance by PPARdelta. PLOS Biol 2004, 2:e294.

46. Grober J, Zaghini I, Fujii H, Jones SA, Kliewer SA, Willson TM, Ono T, Besnard P: Identification of a bile acid-responsive element in the human ileal bile acid-binding protein gene. Involvement of the farnesoid X receptor/9-cis-retinoic acid receptor heterodimer. J Biol Chem 1999, 274:29749-29754.

47. Altmann SW, Davis HR Jr, Zhu LJ, Yao X, Hoos LM, Tetzloff G, Iyer SP, Maguire M, Golovko A, Zeng M, Wang L, Murgolo N, Graziano MP: Niemann-Pick C1 Like 1 protein is critical for intestinal cholesterol absorption. Science 2004, 303:1201-1204. 
48. Leibowitz MD, Ardecky RJ, Boehm MF, Broderick CL, Carfagna MA, Crombie DL, D'Arrigo J, Etgen GJ, Faul MM, Grese TA, Havel H, Hein NI, Heyman RA, Jolley D, Klausing K, Liu S, Mais DE, Mapes CM, Marschke KB, Michellys PY, Montrose-Rafizadeh C, Ogilvie KM, Pascual B, Rungta D, Tyhonas JS, Urcan MS, Wardlow M, Yumibe N, Reifel-Miller A: Biological characterization of a heterodimer-selective retinoid $\mathrm{X}$ receptor modulator: potential benefits for the treatment of type 2 diabetes. Endocrinology 2006, 147:1044-1053.

49. Liu YL, Sennitt MV, Hislop DC, Crombie DL, Heyman RA, Cawthorne MA: Retinoid $X$ receptor agonists have anti-obesity effects and improve insulin sensitivity in Zucker fa/fa rats. Int J Obes Relat Metab Disord 2000, 24:997-1004.

50. Nguyen MT, Satoh H, Favelyukis S, Babendure J L, Imamura T, Sbodio Jl, Zalevsky J, Dahiyat BI, Chi NW, Olefsky JM: JNK and tumor necrosis factoralpha mediate free fatty acid-induced insulin resistance in 3 T3-L1 adipocytes. J Biol Chem 2005, 280:35361-35371.

51. Bastard JP, Maachi M, Lagathu C, Kim MJ, Caron M, Vidal H, Capeau J, Feve B: Recent advances in the relationship between obesity, inflammation, and insulin resistance. Eur Cytokine Netw 2006, 17:4-12.

52. Hotamisligil GS: Role of endoplasmic reticulum stress and c-Jun NH2terminal kinase pathways in inflammation and origin of obesity and diabetes. Diabetes 2005, 54(Suppl 2):S73-S78.

53. Ravussin E, Smith SR: Increased fat intake, impaired fat oxidation, and failure of fat cell proliferation result in ectopic fat storage, insulin resistance, and type 2 diabetes mellitus. Ann N Y Acad Sci 2002, 967:363-378.

54. Gao M, Bu L, Ma Y, Liu D: Concurrent activation of liver $X$ receptor and peroxisome proliferator-activated receptor alpha exacerbates hepatic steatosis in high fat diet-induced obese mice. PLoS One 2013, 8:e65641.

55. Oosterveer MH, Grefhorst A, van Dijk TH, Havinga R, Staels B, Kuipers F Groen AK, Reijngoud DJ: Fenofibrate simultaneously induces hepatic fatty acid oxidation, synthesis, and elongation in mice. J Biol Chem 2009, 284:34036-34044

56. Raffin TA: Physicians and animal experimentation. West J Med 1991, 155:307-308.

57. Oosterveer MH, van Dijk TH, Grefhorst A, Bloks WW, Havinga R, Kuipers F, Reijngoud DJ: Lxralpha deficiency hampers the hepatic adaptive response to fasting in mice. J Biol Chem 2008, 283:25437-25445.

58. Mandard S, Stienstra R, Escher P, Tan NS, Kim I, Gonzalez FJ, Wahli W, Desvergne B, Muller M, Kersten S: Glycogen synthase 2 is a novel target gene of peroxisome proliferator-activated receptors. Cell Mol Life Sci 2007, 64:1145-1157.

59. Kintscher U, Law RE: PPARgamma-mediated insulin sensitization: the importance of fat versus muscle. Am J Physiol Endocrinol Metab 2005, 288:E287-E291.

60. Laffitte BA, Chao LC, Li J, Walczak R, Hummasti S, Joseph SB, Castrillo A, Wilpitz DC, Mangelsdorf DJ, Collins JL, Saez E, Tontonoz P: Activation of liver $\mathrm{X}$ receptor improves glucose tolerance through coordinate regulation of glucose metabolism in liver and adipose tissue. Proc Natl Acad Sci U S A 2003, 100:5419-5424.

61. Choi JH, Banks AS, Kamenecka TM, Busby SA, Chalmers MJ, Kumar N, Kuruvilla DS, Shin Y, He Y, Bruning JB, Marciano DP, Cameron MD, Laznik D, Jurczak MJ, Schürer SC, Vidović D, Shulman Gl, Spiegelman BM, Griffin PR: Antidiabetic actions of a non-agonist PPARgamma ligand blocking Cdk5-mediated phosphorylation. Nature 2011, 477:477-481.

62. Alvarez $R$, Checa M, Brun S, Viñas O, Mampel T, Iglesias R, Giralt M: Villarroya : Both retinoic-acid-receptor- and retinoid-X-receptor-dependent signaling pathways mediate the induction of the brown-adipose-tissueuncoupling-protein-1 gene by retinoids. Biochem J 2000, 345:91-97.

63. Barbera MJ, Schluter A, Pedraza N, Iglesias R, Villarroya F, Giralt M: Peroxisome proliferator-activated receptor alpha activates transcription of the brown fat uncoupling protein-1 gene: $A$ link between regulation of the thermogenic and lipid oxidation pathways in the brown fat cell. J Biol Chem 2001, 276(2):1486-1493.

64. Nedergaard J, Petrovic N, Lindgren EM, Jacobsson A, Cannon B: PPARgamma in the control of brown adipocyte differentiation. Biochim Biophys Acta 2005, 1740(2):293-304.

65. Choi CS, Fillmore JJ, Kim JK, Liu ZX, Kim S, Collier EF, Kulkarni A, Distefano A, Hwang YJ, Kahn M, Chen Y, Yu C, Moore IK, Reznick RM, Higashimori T, Shulman Gl: Overexpression of uncoupling protein 3 in skeletal muscle protects against fat-induced insulin resistance. J Clin Invest 2007, 117:1995-2003.
66. Seifert EL, Bezaire V, Estey C, Harper ME: Essential role for uncoupling protein-3 in mitochondrial adaptation to fasting but not in fatty acid oxidation or fatty acid anion export. J Biol Chem 2008, 283:25124-25131.

67. Mailloux RJ, Dumouchel T, Aguer C, de Kemp R, Beanlands R, Harper ME: Hexokinase II acts through UCP3 to suppress mitochondrial reactive oxygen species production and maintain aerobic respiration. Biochem J 2011, 437:301-311.

68. Kern PA, Simsolo RB, Fournier M: Effect of Weight Loss on Muscle Fiber Type, Fiber Size, Capillarity, and Succinate Dehydrogenase Activity in Humans. J Clin Endocrinol Metabol 1999, 84:4185-4190.

69. Patti ME, Butte AJ, Crunkhorn S, Cusi K, Berria R, Kashyap S, Miyazaki Y, Kohane I, Costello M, Saccone R, Landaker EJ, Goldfine AB, Mun E, DeFronzo $\mathrm{R}$, Finlayson J, Kahn CR, Mandarino $\mathrm{L}$ : Coordinated reduction of genes of oxidative metabolism in humans with insulin resistance and diabetes: Potential role of PGC1 and NRF1. Proc Natl Acad Sci U S A 2003, 100:8466-8471. PNAS (2003)100:8466.

70. Solanes G, Pedraza N, Calvo V, Vidal-Puig A, Lowell BB, Villarroya F: Thyroid hormones directly activate the expression of the human and mouse uncoupling protein-3 genes through a thyroid response element in the proximal promoter region. Biochem J 2005, 386:505-513.

71. Campbell MC, Anderson GW, Mariash CN: Human spot 14 glucose and thyroid hormone response: characterization and thyroid hormone response element identification. Endocrinology 2003, 144:5242-5248.

72. Lalloyer F, Fiévet C, Lestavel S, Torpier G, van der Veen J, Touche V, Bultel S, Yous S, Kuipers F, Paumelle R, Fruchart JC, Staels B, Tailleux A: The RXR agonist bexarotene improves cholesterol homeostasis and inhibits atherosclerosis progression in a mouse model of mixed dyslipidemia. Arterioscler Thromb Vasc Biol 2006, 26:2731-2737.

doi:10.1186/1758-5996-6-83

Cite this article as: Sadasivuni et al.: CNX-013-B2, a unique pan tissue acting rexinoid, modulates several nuclear receptors and controls multiple risk factors of the metabolic syndrome without risk of hypertriglyceridemia, hepatomegaly and body weight gain in animal models. Diabetology \& Metabolic Syndrome 2014 6:83.

\section{Submit your next manuscript to BioMed Central and take full advantage of:}

- Convenient online submission

- Thorough peer review

- No space constraints or color figure charges

- Immediate publication on acceptance

- Inclusion in PubMed, CAS, Scopus and Google Scholar

- Research which is freely available for redistribution 